\title{
TLR4 Asp299Gly (rs4986790) polymorphism and coronary artery disease: A meta-analysis
}

Rui Chen, Ning Gu, Ying Gao, Wei Cen

Background. Previous studies have shown conflicting results on the association between toll-like receptor 4 (TLR4) Asp299Gly (rs4986790) polymorphism and coronary artery disease (CAD). The aim of this study was to evaluate the influence of TLR4 Asp299Gly polymorphism on CAD risk, CRP level and the number of stenotic coronary arteries, as well as to investigate whether $\mathrm{G}$ allele carriers would benefit more from statin treatment.

Methods. PubMed, EMBASE, and CNKI databases were searched until May 2015. All the statistical tests were performed using $R$ version 3.1.2. Odds ratio (OR) and $95 \%$ confidence interval (Cl) were used to assess the association between TLR4 Asp299Gly polymorphism and CAD risk, the number of stenotic vessels, and the incidence of cardiovascular events according to statin-treated patients. Weighted mean difference (WMD) was calculated for the association between Asp299Gly and CRP level. Results. Overall, 12 case-control studies with 10,258 cases and 5891 controls were included, and no association of TLR4Asp299Gly polymorphism with $C A D$ was found ( $G$ allele vs. A allele: $O R=0.97,95 \%$ $\mathrm{Cl}=[0.81,1.17], \mathrm{p}=0.75 ; \mathrm{AA}$ vs. $\mathrm{GG}+\mathrm{AG}: \mathrm{OR}=0.97,95 \% \mathrm{Cl}=[0.80,1.18], \mathrm{p}=0.76 ; \mathrm{GG}$ vs. $A G+A A: O R=1.08,95 \% C l=[0.57,2.02], p=0.82 ; A G$ vs. $A A+G G: O R=1.03,95 \%$ $\mathrm{Cl}=[0.85,1.25], \mathrm{p}=0.74)$. Also, no association was noted between Asp299Gly and CRP level (WMD $=-0.10,95 \% \mathrm{Cl}=[-0.62,0.41], \mathrm{P}=0.69)$. Furthermore, no synergistic effect of statin and 299Gly was reported (Statin_AA v.s Statin_AG/GG: OR=1.12, 95\% Cl= $[0.41,3.09]$, $\mathrm{p}=0.82$ ). Discussion. This meta-analysis suggests no association of TLR4 Asp299Gly polymorphism with CAD and CRP level. It is further indicated that the $G$ allele carriers may not benefit more from statin treatment. Further studies should include large sample size and high-quality literature to understand this issue in depth. 


\section{TLR4 Asp299Gly (rs4986790) Polymorphism and Coronary}

\section{Artery Disease: A Meta-analysis}

3 Rui Chen ${ }^{1}$, Ning $\mathrm{Gu}^{2}$, Ying Gao ${ }^{1}$, Wei Cen ${ }^{1}$

$4{ }^{1}$ The First Clinical College, Nanjing University of Chinese Medicine, Nanjing, Jiangsu, China

52 Department of Cardiology, The Third Affiliated Hospital of Nanjing University of Chinese Medicine, Nanjing,

6 Jiangsu, China

7

8 Corresponding Author:

9 Ning $\mathrm{Gu}^{2}$

10 No 1. Jinling Road, Nanjing, Jiangsu, 210001, China

11 Email address: Ning Gu, guning_2@163.com 
40

41

42

43

44

45

46

47

48

49

50

51

52

53

54

55

56

57

58

59

60

61

62

63

64

65

66

67

68

69

70

71

72

73

74

75

76

77

78

79

80

\section{ABSTRACT}

Background. Previous studies have shown conflicting results on the association between tolllike receptor 4 (TLR4) Asp299Gly (rs4986790) polymorphism and coronary artery disease (CAD). The aim of this study was to evaluate the influence of TLR4 Asp299Gly polymorphism on CAD risk, CRP level and the number of stenotic coronary arteries, as well as to investigate whether $\mathrm{G}$ allele carriers would benefit more from statin treatment.

Methods. PubMed, EMBASE, and CNKI databases were searched until May 2015. All the statistical tests were performed using $\mathrm{R}$ version 3.1.2. Odds ratio (OR) and $95 \%$ confidence interval (CI) were used to assess the association between TLR4 Asp299Gly polymorphism and CAD risk, the number of stenotic vessels, and the incidence of cardiovascular events according to statin-treated patients. Weighted mean difference (WMD) was calculated for the association between Asp299Gly and CRP level.

Results. Overall, 12 case-control studies with 10,258 cases and 5891 controls were included, and no association of TLR4Asp299Gly polymorphism with CAD was found ( $\mathrm{G}$ allele vs. A allele: $\mathrm{OR}=0.97,95 \% \mathrm{CI}=[0.81,1.17], \mathrm{p}=0.75$; $\mathrm{AA}$ vs. $\mathrm{GG}+\mathrm{AG}: \mathrm{OR}=0.97,95 \% \mathrm{CI}=[0.80,1.18]$, $\mathrm{p}=0.76$; $\mathrm{GG}$ vs. $\mathrm{AG}+\mathrm{AA}: \mathrm{OR}=1.08,95 \% \mathrm{CI}=[0.57,2.02], \mathrm{p}=0.82 ; \mathrm{AG}$ vs. $\mathrm{AA}+\mathrm{GG}: \mathrm{OR}=1.03$, $95 \% \mathrm{CI}=[0.85,1.25], \mathrm{p}=0.74)$. Also, no association was noted between Asp299Gly and CRP level $(\mathrm{WMD}=-0.10,95 \% \mathrm{CI}=[-0.62,0.41], \mathrm{P}=0.69)$. Furthermore, no synergistic effect of statin and 299Gly was reported (Statin_AA v.s Statin_AG/GG: OR=1.12, 95\% CI= [0.41, 3.09], $\mathrm{p}=0.82$ ).

Discussion. This meta-analysis suggests no association of TLR4 Asp299Gly polymorphism with CAD and CRP level. It is further indicated that the G allele carriers may not benefit more from statin treatment. Further studies should include large sample size and high-quality literature to understand this issue in depth.

\section{INTRODUCTION}

Coronary artery disease (CAD), resulting from atherosclerosis (AS), has become the leading cause of disability and death globally (Murray et al., 2012). Evidence suggests that inflammation and immunity play a key role in the pathogenesis of AS and CAD (Ross, 1999; Libby, Lichtman \& Hansson, 2013). Moreover, as a pattern recognition receptor of the innate immune system, toll-like receptor 4 (TLR4) expression is increased in human atherosclerotic lesions (Edfeldt et al., 2002). Various ligands (e.g., lipopolysaccharide (LPS), heat shock protein (HSP), minimally oxidized low-density lipoprotein (mmLDL), fibrinogen) can bind to TLR4, and then myeloid differentiation factor 88 (MyD88)-dependent or MyD88-independent signal pathway is activated, resulting in inappropriate immune activation, which consequently contributes to the onset and rupture of AS plaques (Dekker et al., 2010; Miller et al., 2012) . 
81 Human TLR4 is located in 9q32-q33 region, and contains three exons. TLR4 activity and 82 function seem to be modulated by genetic variations, especially single nucleotide polymorphisms 83 (SNPs) (Balistreri et al., 2009). Asp299Gly (+896A/G, rs4986790) is one of the only two SNPs in TLR4 that have a frequency greater than $5 \%$ in humans (Balistreri et al., 2009); the other is Thr399Ile $(+1196 \mathrm{C} / \mathrm{T}$, rs4986791) and a high degree of linkage disequilibrium (LD) exists between them. As most of the variations, Asp299Gly is in the leucine-rich repeat (LRR) domain of Exon 3 which is associated with the recognition of pathogen- associated molecular patterns (PAMPs) (e.g., mmLDL) (Smirnova et al., 2000). Because of a glycine residue substituting for aspartic acid at amino acid position 299 (nucleotide substitution 896A $>\mathrm{G}$ ), the extracellular domain of TLR4 is changed, leading to an attenuate signal pathway, blunted response to inhaled LPS, decreased production of inflammatory cytokines (Arbour et al., 2000), and reduced risk of the progression of atherosclerosis (Kiechl et al., 2002). Numerous studies have focused on the association between the Asp299Gly TLR4 polymorphism and CAD. Some reports suggested a protective effect of TLR4 Asp299Gly on CAD (Boekholdt et al., 2003; Ameziane et al., 2003; Kolek et al., 2004; Balistreri et al., 2004; Berg et al., 2009). In contrast, one study found that men with the 299Gly TLR4 genotype had an increased risk of myocardial infarction (MI) (Edfeldt et al., 2004), while other reports showed no obvious association between 299Gly and CAD (Morange et al., 2004; Zee et al., 2005; Koch et al., 2006; O'Halloran et al., 2006; Nebel et al., 2007; Beijk et al., 2010; Džumhur et al., 2012; Martínez-Ríos et al., 2013; Golovkin et al., 2014; Guven et al., 2015). Based on these, many studies have investigated the relationship between the severity of coronary artery stenosis and Asp299Gly, and obtained inconsistent results (Boekholdt et al., 2003; Yang, Holloway \& Ye, 2003; Hernesniemia et al., 2006; Džumhur et al., 2012; Guven et al., 2015). Furthermore, based on the direct anti-inflammatory effect of statin (Crisby et al., 2001; Ridker et al., 2009), Boekholdt et al. (Boekholdt et al., 2003) stated that 299Gly can affect the efficacy of statin in preventing cardiovascular events, and thus the carriers of the variant allele benefit significantly from statin treatment; however, the same phenomenon was not found in other reports (Kolek et al., 2004; Beijk et al., 2010). The issue whether a synergistic effect of statin and 299Gly exists is still controversial. In addition, Creactive protein (CRP) serves as a useful biomarker of inflammatory diseases, and is also considered as an independent risk factor to predict first and recurrent cardiovascular events; its level with TLR4 Asp299Gly has gained enormous attention (Kiechl et al., 2002; Edfeldt et al., 2004; Kolek et al., 2004; Netea et al., 2004; Hernesniemia et al., 2006; Beijk et al., 2010). In other words, a number of studies have been carried out on Asp299Gly and CAD, and the results are quite inconsistent. Thus, a meta-analysis is needed for further insights into the association between TLR4 Asp299Gly and the CAD risk, the CRP level and the number of stenotic coronary arteries; and to investigate whether a synergistic effect between statin and 299Gly exists.

\section{MATERIALS AND METHODS}

Literature research. This meta-analysis followed the Preferred Reporting Items for Systematic 
122 Reviews and Meta-analyses (PRISMA) statement (Moher et al., 2010). PubMed, EMBASE, and CNKI databases were used to search relevant articles within a range of published years from January 1, 2000 to May 30, 2015. The full search strategy (for PubMed) about the association between TLR4 Asp299Gly polymorphism and CAD was as follows: "Toll-like receptor-4 or TLR4" AND "coronary heart disease or CHD or coronary artery disease or CAD or cardiovascular disease or CVD or myocardial infarction or MI" AND "polymorphism or variant". The full search strategy about the association of Asp299Gly polymorphism with CRP level was as follows: "Toll-like receptor-4 or TLR4" AND "coronary heart disease or CHD or coronary artery disease or CAD or cardiovascular disease or CVD or myocardial infarction or MI" AND "polymorphism or variant" AND "CRP or C-reactive protein". For the study of the synergistic effect between statin and 299Gly, the following search strategy was used: "Toll-like receptor-4 or TLR4" AND "coronary heart disease or CHD or coronary artery disease or CAD or cardiovascular disease or CVD or myocardial infarction or MI" AND "polymorphism or variant" AND "statin". To avoid missing articles, the references cited in the research papers and review articles were examined as well.

Inclusion and exclusion criteria. The inclusion criteria for the studies about the association between TLR4 Asp299Gly polymorphism and CAD were as follows: (a) published case-control studies, and the control group should be the population without CAD; (b) clear diagnosis criteria of CAD; (c) studies supplied the number of individual genotypes in CAD cases and controls; (d) sufficient data for estimating an odds ratio (OR) or weighted mean difference (WMD) with 95\% confidence interval (CI); (e) written in English or Chinese. The inclusion criteria for the studies about the association of TLR4 Asp299Gly polymorphism with CRP level, the number of stenosis coronary arteries, and the incidence of cardiovascular events with statin treatment were as follows: (a) integrated data; (b) sufficient data for estimating an odds ratio (OR) or weighted mean difference (WMD) with 95\% confidence interval (CI); (c) measurement data had definite unit; (d) written in English or Chinese.

All reviews, case reports, animal studies and reports with incomplete data were excluded.

Data extraction and quality assessment. Data from the eligible studies were extracted by two authors based on the aforementioned criteria; if these two authors could not reach a consensus, the result was reviewed by a third author. Finally, the following information was recorded for each study: first author, year of publication, ethnicity, region, disease category, sample size, sex ratio, the number of allele and genotype counts of cases and controls, the frequencies of AA and $\mathrm{AG} / \mathrm{GG}$ genotypes in patients with one, two, or three coronary arteries with $>50 \%$ stenosis, the frequencies of $\mathrm{AA}$ and $\mathrm{AG} / \mathrm{GG}$ genotypes in the patients with or without the incidence of cardiovascular events according to statin treatment, and the CRP level in AA and AG/GG groups. Whether these studies were in Hardy-Weinberg equilibrium (HWE) was also recorded $P<0.05$ was considered as a significant deviation from HWE). Quality assessment of studies included in the meta-analysis was conducted by two authors using the Newcastle-Ottawa Scale (NOS) (Wells et al., 2011). Scores were given for subject selection (i.e., adequateness of the case definition, 
163 representativeness of the cases, selection of controls, and definition of controls) and the 164 comparability of the groups (i.e., comparability of cases and controls on the basis of the design 165 or analysis) as well as measurement of exposure (i.e., ascertainment of exposure, same method of 166 ascertainment for cases and controls, and non-response rate). NOS scores ranged from 0 to 9.

Studies with a NOS score $\geqslant 6$ were considered to be of high quality.

168

169

170

171

172

173

174

175

176

177

178

179

180

181

182

183

184

185

186

187

188

189

190

191

192

193

194

195

196

197

198

199

200

201

202

Statistical analysis. This meta-analysis used four gene models: allelic model (G allele vs. A allele), dominant model (AA vs. $G G+A G$ ), recessive model (GG vs. AG + AA) and superdominant model (AG vs. AA+GG), to explore the association between the CAD risk and TLR4 Asp299Gly polymorphism. In addition, OR and 95\% CI were calculated to assess the association between Asp299Gly and CAD risk, the number of stenotic vessels, and the incidence of cardiovascular events according to statin treatment; WMD was calculated for the association between Asp299Gly and CRP level.

Heterogeneity among studies was evaluated using the Cochran's Q statistic and the $\mathrm{I}^{2}$ statistic $(P$ $<0.10$ and $\mathrm{I}^{2}>50 \%$ indicated evidence of heterogeneity) (Higgins \& Thompson, 2002). If no heterogeneity in the data existed, the fixed-effects model was used; otherwise the random-effects model was used (Mantel \& Haenszel, 1959; DerSimonian \& Laird, 1986). Subgroup analysis (based on the type of CAD) and meta-regression were performed to explore the source of heterogeneity. In order to evaluate the stability of the results, sensitivity analysis was used, which meant omitting one study at a time, and then compared to show whether a significant difference existed between the former and the latter results. Furthermore, Begg's funnel plot and Egger's regression test were used to test publication bias $(P<0.05$ was considered the representative of statistically significant publication bias) (Begg \& Mazumdar, 1994; Egger et al., 1997). At last, cumulative meta-analysis was applied to reflect dynamic changes in the results according to different publication years. The statistical analyses were performed using metafor 1.9-5 (R 3.1.2).

\section{RESULTS}

Association between Asp299Gly and CAD

Study characteristics. According to the PRISMA-statement flow diagram (Fig. 1), 17 full-text articles were assessed for eligibility, five (Boekholdt et al., 2003; Kolek et al., 2004; Holloway, Yang \& Ye, 2005; Hernesniemia et al., 2006; Beijk et al., 2010) of which were excluded, because they were not proper case-control studies, despite being of high quality. Finally, 12 articles (NOS score > 6) (Ameziane et al., 2003; Balistreri et al., 2004; Edfeldt et al., 2004; Morange et al., 2004; Zee et al., 2005; Koch et al., 2006; O'Halloran et al., 2006; Nebel et al., 2007; Džumhur et al., 2012; Martínez-Ríos et al., 2013; Golovkin et al., 2014; Guven et al., 2015) were included with 10,258 cases and 5891 controls. Most of the studies were conducted on Caucasian populations. The main characteristics of the studies are listed in Table 1.

Meta-analysis results of overall study. The heterogeneity of each gene model was as follows: allelic model ( $\mathrm{G}$ allele vs. A allele): $\mathrm{P}_{\mathrm{Q}}=0.0019, \mathrm{I}^{2}=61.34 \%$; dominant model (AA vs. $\mathrm{GG}+$ 
203

204

205

206

207

208

209

210

211

212

213

214

215

216

217

218

219

220

221

222

223

224

225

226

227

228

229

230

231

232

233

234

235

236

237

238

239

240

241

$\mathrm{AG}): \mathrm{P}_{\mathrm{Q}}=0.0021, \mathrm{I}^{2}=61.13 \%$; recessive model $(\mathrm{GG}$ vs. $\mathrm{AG}+\mathrm{AA}): \mathrm{P}_{\mathrm{Q}}=0.97, \mathrm{I}^{2}=0.00 \%$; super-dominant model (AG vs. $\mathrm{AA}+\mathrm{GG}): \mathrm{P}_{\mathrm{Q}}=0.0039, \mathrm{I}^{2}=58.70 \%$. Fixed-effects model was used for recessive model, and random-effects model was used for the other three models. $G$ allele vs. A allele: $\mathrm{OR}=0.97,95 \% \mathrm{CI}=(0.81,1.17), P=0.75 ; \mathrm{AA}$ vs. $\mathrm{GG}+\mathrm{AG}$ : $\mathrm{OR}=0.97,95 \%$ $\mathrm{CI}=(0.80,1.18), P=0.76$; $\mathrm{GG}$ vs. $\mathrm{AG}+\mathrm{AA}: \mathrm{OR}=1.08,95 \% \mathrm{CI}=(0.57,2.02), P=0.82 ; \mathrm{AG}$ vs. $\mathrm{AA}+\mathrm{GG}$ : $\mathrm{OR}=1.03,95 \% \mathrm{CI}=(0.85,1.25), P=0.74$. Overall, no association of TLR4 Asp299Gly polymorphism with CAD was observed. The results are shown in Fig. 2.

Heterogeneity analysis. The heterogeneity could not be effectively removed after subgroups were divided based on the different types of CAD. No association of Asp299Gly with CAD type was noted. To explore the source of heterogeneity further, meta-regression was used. It was found that ethnicity, region, disease category, sex ratio (male/female), and sample size ratio (cases/controls) were not the source of heterogeneity in all the models. In the allelic model, the frequency of $\mathrm{A} / \mathrm{G}$ allele in the control group could explain $56.35 \%$ of $\mathrm{I}^{2}$, which meant part of the source of heterogeneity was explored. However, in the dominant model and the super-dominant model, the frequency of genotypes in the case group could explain $56.86 \%$ and $63.65 \%$ of $\mathrm{I}^{2}$ respectively.

Sensitivity analysis. One study was omitted at a time, and each of them made no obvious difference in the overall meta-analysis estimation, indicating that the results had a favorable stability.

Publication bias. Funnel plots (Fig. 3) intuitively reflected the publication bias. The results of Egger's regression test were as follows: $P=0.25$ for $\mathrm{G}$ allele vs. A allele, $P=0.25$ for AA vs. $\mathrm{GG}+\mathrm{AG}, P=0.37$ for GG vs. AG $+\mathrm{AA}, P=0.16$ for AG vs. AA+GG. Funnel plots with good symmetry and $P$ value $>0.05$ indicated no publication bias in the study.

Cumulative meta-analysis. According to the order of published years, cumulative meta-analysis was performed, and it was found that OR value and 95\% CI tended to be stable, and 95\% CI gradually narrowed, as shown in Fig. 4.

Association between Asp299Gly and the number of stenotic coronary arteries

No association was found between the genotype frequency and the number of coronary arteries with $>50 \%$ stenosis. Details are shown in Supplemental Article S1.

Association between Asp299Gly and CRP level

Study characteristics. Six reports (Kiechl et al., 2002; Edfeldt et al., 2004; Kolek et al., 2004; Netea et al., 2004; Hernesniemia et al., 2006; Beijk et al., 2010) were included, in which the CRP levels of different genotypes (AA, AG/GG) were recorded using median and interquartile ranges or $\bar{x}_{ \pm \mathrm{s}}$. According to the method provided by an article (Hozo, Djulbegovic \& Hozo, 2005), median and interquartile ranges were converted into $\stackrel{2}{x} \pm$ s for the convenience of statistics. Details are shown in Table 2.

Meta-analysis results. Test for heterogeneity: $\mathrm{P}_{\mathrm{Q}}<0.0001, \mathrm{I}^{2}=96.20 \%$, random-effects model 
242

243

244

245

246

247

248

249

250

251

252

253

254

255

256

257

258

259

260

261

262

263

264

265

266

267

268

269

270

271

272

273

274

275

276

277

278

279

280

281

282

was used. $\mathrm{WMD}=-0.10,95 \% \mathrm{CI}=(-0.62,0.41) . P=0.69$. Egger test: $P=0.77$.

Also, no significant difference was found between Asp299Gly and CRP level. Forest plot and funnel plot are shown in Fig. 5. Larger heterogeneity might be caused by different measurement methods for CRP. Due to the lack of raw data, we couldn't know all measurement methods of CRP, namely, we couldn't remove the heterogeneity, so the persuasion of this result was limited.

Synergistic effect of statin and Asp299Gly

No synergistic effect of statin and 299Gly was found. Details are shown in Supplemental Article S2.

\section{DISCUSSION}

The worldwide distribution of $\mathrm{G}$ allele is closely related to the ethnic groups, which might be the result of differences in environmental pressure during human migration (Ferwerda et al., 2007; Ferwerda et al., 2008). TLR4 Asp299Gly polymorphism is rather rare in Asian populations (Lin et al., 2005; Nakada et al., 2005; Kim et al., 2008; Yuan et al., 2010), while 6\%-14\% of the Caucasian population is positive for Asp299Gly (Balistreri et al.,2009).For this reason, previous studies were mainly carried out in Europe. To clarify the relationship between CAD and Asp299Gly more effectively, it is worth mentioning that in the present meta-analysis, reports about Asp299Gly from Mexican and Turkish populations were included for more reliable studies. This meta-analysis showed no association between Asp299Gly and CAD. Subsequent subgroup analysis and sensitivity analysis, as well as the study on the association between Asp299Gly and the number of stenotic coronary arteries all confirmed this conclusion. This result was also consistent with the conclusions of the other two previous meta-analyses (Zhang et al., 2012; Yin et al., 2014).

In addition, CRP, a nonspecific acute phase protein, is a useful biomarker of inflammation. It is also considered as an independent risk factor to predict first and recurrent cardiovascular events such as MI or stroke (Kaptoge et al., 2012; Wennberg et al., 2012). Furthermore, in a randomized trial, statin therapy significantly reduced the incidence of major cardiovascular events among people without hyperlipidemia but with elevated CRP level (Ridker et al., 2008), which further supported the anti- inflammatory effect of statin. Thus, the present meta-analysis analyzed the association of Asp299Gly with CRP level, and explored whether G allele carriers could benefit more from statin treatment. It showed no obvious association between Asp299Gly and CRP level, and G allele carriers could not benefit more from statin treatment. However, the conclusion was underpowered due to the insufficient number of articles included and large heterogeneity of this meta-analysis. Hence, future studies should include large sample size and high quality literature to understand this issue in depth.

This meta-analysis has certain limitations as follows: First, CAD is influenced by multiple genetic mutations (Enquobahrie et al., 2008), so some interaction among genetic variations might exist widely. For example, some articles (Morange et al., 2004; Vainas et al., 2006) considered the synergistic effect of TLR4/Asp299Gly and CD14/C-260T, and one of them 
283 (Vainas et al., 2006) found that the carriers with TLR4 G allele/CD14 TT genotype, rather than each SNP individually, were associated with the atherosclerotic disease. Also, some reports (Boekholdt et al., 2003; Edfeldt et al., 2004; Koch et al., 2006; Guven et al., 2015) were available about the combination effect of TLR4/Asp299Gly and TLR4/ Thr399Ile. So, it can be speculated that the interaction among SNPs in TLR4 and TLRs and other signal molecules may exist. Some literature suggests that the analysis of a number of polymorphic genetic markers is more informative than the analysis of a single polymorphism (Olivieri et al., 2006); however, this meta-analysis did not involve the interaction among SNPs. Second, CAD is a multifactorial disease, and its incidence and development are closely related to environmental and life-style factors. Hence, a small contribution of a SNP to CAD might be obscured by the presence of various dominant risk factors (Incalcaterra et al., 2013). Patients with CAD with different gender, age, and life-style have different pathophysiological characteristics (Edfeldt et al., 2004; Olivieri et al., 2006; Incalcaterra et al., 2010). Some articles have considered the influence of these factors, while othershave not. Due to the lack of original data, the influence of life-style (e.g., smoking) on the results of the meta-analysis was not investigated. Third, although the meta-analysis was based on detailed inclusion and exclusion criteria, some important uncontrollable factors still existed, such as different study design, different source of controls, and different environment. This might be the reason why the heterogeneity could not be removed effectively after subgroups were divided based on different types of CAD.

In conclusion, this meta-analysis suggested no association of TLR4 Asp299Gly polymorphism with CAD and CRP level. Moreover, the findings indicated that the $\mathrm{G}$ allele carriers might not benefit more from statin treatment. However, these results should be confirmed by conducting more high-quality studies in future.

\section{Acknowledgements}

We thank Zhibin Quan (School of Computer Science and Engineering, Southeast University) for technical discussion.

\section{References}

Ameziane N, Beillat T, Verpillat P, Chollet-Martin S, Aumont MC, Seknadji P, Lamotte M, Lebret D, Ollivier V, Prost D. 2003. Association of the Toll-like receptor 4 gene Asp299Gly polymorphism with acute coronary events. Arteriosclerosis, Thrombosis, and Vascular Biology 23:61-64. DOI: 10.1161/01.ATV.0000101191.92392.1D

Arbour NC, Lorenz E, Schutte BC, Zabner J, Kline JN, Jones M, Frees K, Watt JL, Schwartz DA. 2000. TLR4 mutations are associated with endotoxin hyporesponsiveness in humans. Nature Genetics 25:187-191. DOI: 10.1038/76048

Balistreri CR, Candore G, Colonna-Romano G, Lio D, Caruso M, Hoffmann E, Franceschi C, Caruso C. 2004. Role of Toll-like receptor 4 in acute myocardial infarction and longevity. The 
Journal of the American Medical Association 292:2339-2340. DOI: 10.1001/jama.292.19.2339.

Balistreri CR, Colonna-Romano G, Lio D, Candore G, Caruso C.2009.TLR4 Polymorphism and Aging: Implications for the Pathophysiology of Age-Related Disease. Journal of clinical immunology 29:406-415. DOI: 10.1007/s10875-009-9297-5.

Begg CB, Mazumdar M. 1994. Operating characteristics of a rank correlation test for publication bias. Biometrics 50:1088-1101. DOI: 10.2307/2533446

Beijk MAM, Boekholdt SM, Rittersma SZH, Pons D, Zwinderman AH, Doevendans PAF, Tio RA, Tijssen JGP, Jukema JW, de Winter RJ. 2010. Toll-like receptor 4 gene polymorphisms show no association with the risk of clinical or angiographic restenosis after percutaneous coronary intervention. Pharmacogenet Genomics 20:544-552. DOI: 10.1097/FPC.0b013e32833d7b29

Berg KK, Madsen HO, Garred P, Wiseth R, Gunnes S, Videm V. 2009. The additive contribution from inflammatory genetic markers on the severity of cardiovascular disease. Scandinavian Journal of Immunology 691:36-42. DOI: 10.1111/j.1365-3083.2008.02187.x

Boekholdt SM, Agema WRP, Peters RJG, Zwinderman AH, Wall EE, Reitsma PH, Kastelein JJP, Jukema JW, on behalf of the REgression GRowth Evaluation Statin Study (REGRESS) Study Group. 2003. Variants of toll-like receptor 4 modify the efficacy of statin therapy and the risk of cardiovascular events. Circulation 107:2416-2421. DOI:10.1161/01.CIR.0000068311.40161.28

Crisby M, Nordin-Fredriksson G, Shah PK, Yano J, Zhu J, Nilsson J. 2001. Pravastatin treatment increases collagen content and decreases lipid content, inflammation, metalloproteinases, and cell death in human carotid plaques: implications for plaque stabilization. Circulation 103:926933. DOI: 10.1161/01.CIR.103.7.926

Dekker WK, Cheng C, Pasterkamp G, Duckers H. 2010.Toll like receptor 4 in atherosclerosis and plaque destabilization. Atherosclerosis 209:314-320.

DOI:10.1016/j.atherosclerosis.2009.09.075

DerSimonian R, Laird N. 1986. Meta-analysis in clinical trials. Controlled Clinical Trials 7:177188. DOI: $10.1016 / 0197-2456(86) 90046-2$

Džumhur A, Zibar L, Wagner J, Šimundić T, Dembić Z, Barbić J. 2012. Association Studies of Gene Polymorphisms in Toll-Like Receptors 2 and 4 in Croatian Patients with Acute Myocardial Infarction. Scandinavian Journal of Immunology 75, 517-523. DOI: 10.1111/j.13653083.2012.02681.x 
Edfeldt K, Bennet AM, Eriksson P, Frostegård J, Wiman B, Hamsten A, Hansson GK, Faire U, Yan ZQ. 2004. Association of hypo-responsive toll-like receptor 4 variants with risk of myocardial infarction. European Heart Journal 25:1447-1453. DOI:10.1016/j.ehj.2004.05.004

Edfeldt K, Swedenborg J, Hansson GK, Yan ZQ. 2002. Expression of toll-like receptors in human atherosclerotic lesion: a possible pathway for plaque activation. Circulation 105:11581161. DOI: 10.1161/01.CIR.0000012489.17433.31

Egger M, Davey Smith G, Schneider M, Minder C. 1997. Bias in meta-analysis detected by a

Enquobahrie DA, Smith NL, Bis JC, Carty CL, Rice KM, Lumley T, Hindorff LA, Lemaitre RN, Williams MA, Siscovick DS, Heckbert SR, Psaty BM. 2008. Cholesterol Ester Transfer Protein, Interleukin-8, Peroxisome Proliferator Activator Receptor Alpha, and Toll-Like Receptor 4 Genetic Variations and Risk of Incident Nonfatal Myocardial Infarction and Ischemic Stroke.

Ferwerda B, McCall MB, Alonso S, Giamarellos-Bourboulis EJ, Mouktaroudi M, Izagirre N, Syafruddin D, Kibiki G, Cristea T, Hijmans A, Hamann L, Israel S, ElGhazali G, TroyeBlomberg M, Kumpf O, Maiga B, Dolo A, Doumbo O, Hermsen CC, Stalenhoef AFH, van Crevel R, Brunner HG, Oh DY, Schumann RR, de la Rúa C, Sauerwein R, Kullberg BJ, Ven AJAM van der, Meer JWM van der, Netea MG. 2007.TLR4 polymorphisms, infectious diseases, and evolutionary pressure during migration of modern humans. Proceeding of the National Academy of Science of the United States of America 104:16645-16650. DOI: 10.1073/pnas.0704828104

Ferwerda B, McCall MB, Verheijen K, Kullberg BJ, Ven AJAM van der, Meer JWM van der, Netea MG. 2008. Functional consequences of toll like receptor 4 polymorphisms. Molecular Medicine 14:346-352. DOI: 10.2119/2007-00135.Ferwerda

Golovkin AS, Ponasenko AV, Khutornaya MV, Kutikhin AG, Salakhov RR, Yuzhalin AE, Zhidkova II, Barbarash OL, Barbarash LS. 2014. Association of TLR and TREM-1 gene polymorphism with risk of coronary artery disease in a Russian population. Gene 550:101-109. DOI: $10.1016 /$ j.gene.2014.08.022

Guven M, Ismailoglu Z, Batar B, Unal S, Onaran I, Karadag B, Ongen Z. 2015. The effect of genetic polymorphisms of TLR2 and TLR4 in Turkish patients with coronary artery disease. Gene 568:99-102. DOI: 10.1016/j.gene.2015.05.032

Hernesniemia J, Lehtimäki T, Rontu R, Islam MS, Eklund C, Mikkelsson J, Ilveskoski E, 
406 Kajander O, Goebeler S, Viiri LE, Hurme M, Karhunen PJ. 2006. Toll-like receptor 4 407 polymorphism is associated with coronary stenosis but not with the occurrence of acute or old 408 myocardial infarctions. Scandinavian Journal of Clinical and Laboratory Investigation 66:667675. DOI: 10.1080/00365510600933011

Higgins JP, Thompson SG. 2002. Quantifying heterogeneity in a meta-analysis. STATISTICS

Holloway JW, Yang IA, Ye S. 2005. Variation in the toll-like receptor 4 gene and susceptibility to myocardial infarction. Pharmacogenet Genomics 15:15-21. DOI: 10.1097/01213011200501000-00003

Hozo SP, Djulbegovic B, Hozo I. 2005. Estimating the mean and variance from the median, range, and the size of a sample. BMC Medical Research Methodology 5:13. DOI: 10.1186/14712288-5-13

Incalcaterra E, Accardi G, Balistreri CR, Caimi G, Candore G, Caruso M, Caruso C. 2013. ProInflammatory Genetic Markers of Atherosclerosis. Current Atherosclerosis Reports 15:329. DOI: 10.1007/s11883-013-0329-5

Incalcaterra E, Caruso M, Balistreri CR, Candore G, Lo Presti R, Hoffmann E, Caimi G. 2010. Role of genetic polymorphisms in myocardial infarction at young age. Clinical Hemorheology and Microcirculation 46:291-298. DOI: 10.3233/CH-2010-1353

Kaptoge S, Di AE, Pennells L, Wood AM, White IR, Gao P, Walker M, Thompson Ar, Sarwar N, Caslake M, Butterworth AS, Amouyel P, Assmann G, Bakker SJL, Barr ELM, Barrett-Connor E, Benjamin EJ, Björkelund C, Brenner H, Brunner E, Clarke R, Cooper JA, Cremer P, Cushman M, Dagenais GR, D'Agostino RB, Dankner R, Davey-Smith G, Deeg D, Dekker JM, Engström G, Folsom AR, Fowkes FGR, Gallacher J, Gaziano JM, Giampaoli S, Gillum RF, Hofman A, Howard BV, Ingelsson E, Iso H, Jørgensen T, Kiechl S, Kitamura A, Kiyohara Y, Koenig W, Kromhout D, Kuller LH, Lawlor DA, Meade TW, Nissinen A, Nordestgaard BG, Onat A, Panagiotakos DB, Psaty BM, Rodriguez B, Rosengren A, Salomaa V, Kauhanen J, Salonen JT, Shaffer JA, Shea S, Ford I, Stehouwer CDA, Strandberg TE, Tipping RW, Tosetto A, Wassertheil-Smoller S, Wennberg P, Westendorp RG, Whincup PH, Wilhelmsen L, Woodward M, Lowe GDO, Wareham NJ, Khaw KT, Sattar N, Packard CJ, Gudnason V, Ridker PM, Pepys MB, Thompson SG, Daneshm J. 2012.C-reactive protein, fibrinogen, and cardiovascular disease prediction. The New England Journal of Medicine 367: 1310-1320. DOI: 10.1056/NEJMoa1107477

Kiechl S, Lorenz E, Reindl M, Wiedermann CJ, Oberhollenzer F, Bonora E, Willeit J, Schwartz DA. 2002. Toll-like receptor 4 polymorphisms and atherogenesis. The New England Journal of 
447

448

449

450

451

452

453

454

455

456

457

458

459

460

461

462

463

464

465

466

467

468

469

470

471

472

473

474

475

476

477

478

479

480

481

482

483

484

485

486

487

Medicine 347:185-192. DOI: 10.1056/NEJMoa012673

Kim YS, Hwang YJ, Kim SY, Yang SM, Lee KY, Park IB. 2008.Rarity of TLR4 Asp299Gly and Thr399Ile Polymorphisms in the Korean Population. Yonsei Medical Journal 49(1):58-62. DOI: $10.3349 / y m j .2008 .49 .1 .58$

Koch W, Hoppmann P, Pfeufer A, Schomig A, Kastrati A. 2006. Toll-like receptor 4 gene polymorphisms and myocardial infarction: no association in a Caucasian population. European Heart Journal 27:2524-2529. DOI: 10.1093/eurheartj/ehl231

Kolek MJ, Carlquist JF, Muhlestein JB, Whiting BM, Horne BD, Bair TL, Anderson JL. 2004. Toll-like receptor 4 gene Asp299Gly polymorphism is associated with reductions in vascular inflammation, angiographic coronary artery disease, and clinical diabetes. American Heart Journal 148:1034-1040. DOI: 10.1016/j.ahj.2004.05.049

Libby P, Lichtman AH, Hansson GK. 2013. Immune Effector Mechanisms Implicated in Atherosclerosis: From Mice to Humans. Immunity 38:10921104.DOI:10.1016/j.immuni.2013.06.009

Lin YC, Chang YM, Yu JM, Yen JH, Chang JG, Hu CJ. 2005. Toll-like receptor 4 gene C119A but not Asp299Gly polymorphism is associated with ischemic stroke among ethnic Chinese in Taiwan. Atherosclerosis 180: 305-309. DOI:10.1016/j.atherosclerosis.2004.12.022

Mantel N, Haenszel W. 1959. Statistical aspects of the analysis of data from retrospective studies of disease. Journal of the National Cancer Institute 22:719-748.

Martínez-Ríos MA, Vargas-Alarcón G, Vallejo M, Cruz-Martinez E, Pérez-Méndez O, MedinaAndrade Á, Torre-García MD, Pẽna-Duque MA, Fragoso JM. 2013. Toll-like receptor 4 gene polymorphisms and acute coronary syndrome: No association in a Mexican population. Archivos de Cardiología de México 83(4):257-262. DOI: 10.1016/j.acmx.2013.09.001

Miller YI, Choi SH, Wiesner P, Bae YS. 2012. The SYK side of TLR4: Signaling mechanisms in response to LPS and minimally oxidized LDL. British Journal of Pharmacology 167(5): 990-999. DOI: 10.1111/j.1476-5381.2012.02097.x

Moher D, Liberati A, Tetzlaff J, Altman DG; PRISMA Group. 2010. Preferred reporting items for systematic reviews and meta-analyses: the PRISMA statement. Annals of Internal Medicine 151(4):264-269. DOI: 10.7326/0003-4819-151-4-200908180-00135

Morange PE, Tiret L, Saut N, Luc G, Arveiler D, Ferrieres J, Amouyel P, Evans A, Ducimetiere P, Cambien F, Juhan-Vague I, on behalf of the PRIME Study group. 2004. TLR4/Asp299Gly, CD14/C-260T, plasma levels of the soluble receptor CD14 and the risk of coronary heart disease: 
The PRIME Study. European Journal of Human Genetics 12:1041-1049. DOI: 10.1038/sj.ejhg.5201277

Murray CJL, Vos T, Lozano R, Naghavi M, Flaxman AD, Michaud C, Ezzati M, Shibuya K, Salomon JA, Abdalla S, Aboyans V, Abraham J, Ackerman I, Aggarwal R, Ahn SY, Ali MK, AlMazroa MA, Alvarado M, Anderson HR, Anderson LM, Andrews KG, Atkinson C, Baddour LM, Bahalim AN, Barker-Collo S, Barrero LH, Bartels DH, Basáñez MG, Baxter A, Bell ML, Benjamin EJ, Bennett D, Bernabé E, Bhalla K, Bhandari B, Bikbov B, Abdulhak AB, Birbeck G, Black JA, Blencowe H, Blore JD, Blyth F, Bolliger I, Bonaventure A, Boufous S, Bourne R, Boussinesq M, Braithwaite T, Brayne C, Bridgett L, Brooker S, Brooks P, Brugha TS, BryanHancock C, Bucello C, Buchbinder R, Buckle G, Budke CM, Burch M, Peter Burney, Roy Burstein, Bianca Calabria, Benjamin Campbell, Charles E Canter, Carabin H, Carapetis J, Carmona L, Cella C, Che P, Charlson F, Chen HL, Cheng ATA, Chou D, Chugh SS, Coffeng LE, Colan SD, Colquhoun S, Colson KE, Condon J, Connor MD, Cooper LT, Corriere M, Cortinovis M, Vaccaro KC, Couser W, Cowie BC, Criqui MH, Cross M, Dabhadkar KC, Dahiya M, Dahodwala N, Damsere-Derry J, Danaei G, Davis A, Leo DD, Degenhardt L, Dellavalle R, Delossantos A, Denenberg J, Derrett S, Jarlais DCD, Dharmaratne SD, Dherani M, Diaz-Torne C, Dolk H, Dorsey ER, Driscoll T, Duber H, Ebel B, Edmond K, Elbaz A, Ali SE, Erskine H, Erwin PJ, Espindola P, Ewoigbokhan SE, Farzadfar F, Feigin V, Felson DT, Ferrari A, Ferri CP, Fèvre EM, Finucane MM, Flaxman S, Flood L, Foreman K, Forouzanfar MH, Fowkes FGR, Fransen M, Freeman MK, Gabbe BJ, Gabriel SE, Gakidou E, Ganatra HA, Garcia B, Gaspari F, Che, Gillum RF, Gmel G, Gonzalez-Medina D, Gosselin R, Grainger R, Grant B, Groeger J, Guillemin F, Gunnell D, Gupta R, Haagsma J, Hagan H, Halasa YA, Hall W, Haring D, Haro JM, Harrison JE, Havmoeller R, Hay RJ, Higashi H, Hill C, Hoen B, Hoffman H, Hotez PJ, Hoy D, Huang JJ, Ibeanusi SE, Jacobsen KH, James SL, Jarvis D, Jasrasaria R, Jayaraman S, Johns N, Jonas JB, Karthikeyan G, Kassebaum N, Kawakami N, Keren A, Khoo JP, King CH, Knowlton LM, Kobusingye O, Koranteng A, Krishnamurthi R, Laden F, Lalloo R, Laslett LL, Lathlean T, Leasher JL, Lee YY, Leigh J, Levinson D, Lim SS, Limb E, Lin JK, Lipnick M, Lipshultz SE, Liu W, Loane M, Ohno SL, Lyons R, Mabweijano J, MacIntyre MF, Malekzadeh R, Mallinger L, Manivannan S, Marcenes W, March L, Margolis DJ, Marks GB, Marks R, Matsumori A, Matzopoulos R, Mayosi BM, McAnulty JH, McDermott MM, McGill N, McGrath J, Medina-Mora ME, Meltzer M, Memish ZA, Mensah GA, Merriman TR, Meyer AC, Miglioli V, Miller M, Miller TR, Mitchell PB, Mock C, Mocumbi AO, Moffitt TE, Mokdad AA, Monasta L, Montico M, Moradi-Lakeh M, Moran A, Morawska L, Mori R, Murdoch ME, Mwaniki MK, Naidoo K, Nair MN, Naldi L, Narayan KMV, Nelson PK, Nelson RG, Nevitt MC, Newton CR, Nolte S, Norman P, Norman R, O'Donnell M, O'Hanlon S, Olives C, Omer SB, Ortblad K, Osborne R, Ozgediz D, Page A, Pahari B, Pandian JD, Rivero AP, Patten SB, Pearce N, Padilla RP, Perez-Ruiz F, Perico N, Pesudovs K, Phillips D, Phillips MR, Pierce K, Pion S, Polanczyk GV, Polinder S, Pope CA, Popova S, Porrini E, Pourmalek F, Prince M, Pullan RL, Ramaiah KD, Ranganathan D, Razavi H, Regan M, Rehm JT, Rein DB, Remuzzi G, Richardson K, Rivara FP, Roberts T, Robinson C, Leòn FRD, Ronfani L, Room R, 
529 Rosenfeld LC, Rushton L, Sacco RL, Saha S, Sampson U, Sanchez-Riera L, Sanman E, 530 Schwebel DC, Scott JG, Segui-Gomez M, Shahraz S, Shepard DS, Shin H, Shivakoti R, 531 Silberberg D, Singh D, Singh GM, Singh JA, Singleton J, Sleet DA, Sliwa K, Smith E, Smith 532 JL, Stapelberg NJC, Steer A, Steiner T, Stolk WA, Stovner LJ, Sudfeld C, Syed S, Tamburlini G, 533 Tavakkoli M, Taylor HR, Taylor JA, Taylor WJ, Thomas B, Thomson WM, Thurston GD, 534 Tleyjeh IM, Tonelli M, Towbin JA, Truelsen T, Tsilimbaris MK, Ubeda C, Undurraga EA, 535 Werf MJ, Os J, Vavilala MS, Venketasubramanian N, Wang M, Wang W, Watt K, Weatherall 536 DJ, Weinstock MA, Weintraub R, Weisskopf MG, Weissman MM, White RA, Whiteford H, 537 Wiebe N, Wiersma ST, Wilkinson JD, Williams HC, Williams SRM, Witt E, Wolfe F, Woolf 538 AD, Wulf S, Yeh PH, Zaidi AKM, Zheng ZJ, Zonies D, Lopez AD. 2012.Disability adjusted life 539 years DALYs for 291 diseases and injuries in 21 regions, 1990-2010: a systematic analysis for 540 the Global Burden of Disease Study. Lancet 380:2197-2223. DOI: 10.1016/S0140$5416736(12) 61689-4$

Nakada TA, Hirasawa H, Oda S, Shiga H, Matsuda KI, Nakamura M, Watanabe E, Abe R, Hatano M, Tokuhisa T. 2005. Influence of toll-like receptor 4, CD14, tumor necrosis factor, and interleukine-10 gene polymorphisms on clinical outcome in Japanese critically ill patients. Journal of Surgical Research 129:322-328. DOI: 10.1016/j.jss.2005.05.020

Nebel A, Flachsbart F, Schäfer A, Nothnagel M, Nikolaus S, Mokhtari NEE, Schreiber S. 2007. Role of the toll-like receptor 4 polymorphism Asp299Gly in longevity and myocardial infarction in German men. Mechanisms of Ageing and Development 128:409-11. DOI: 10.1016/j.mad.2007.04.001

Netea MG, Hijmans A, Wissen S, Smilde TJ, Trip MD, Kullberg BJ, De Boo T, Van der Meer JWM, Kastelein JJP, Stalenhorf AFH. 2004. Toll-like receptor-4 Asp299Gly polymorphism does not influence progression of atherosclerosis in patients with familial hypercholesterolaemia. European Journal of Clinical Investigation 342:94-99. DOI: 10.1111/j.1365-2362.2004.01303.x

O'Halloran AM, Stanton A, O'Brien E, Shields DC. 2006. The impact on coronary artery disease of common polymorphisms known to modulate responses to pathogens. Annals of Human Genetics 70:934-945. DOI: 10.1111/j.1469-1809.2006.00281.x

Olivieri F, Antonicelli R, Cardelli M, Marchegiani F, Cavallone L, Mocchegiani E, Franceschi C. 2006. Genetic polymorphisms of inflammatory cytokines and myocardial infarction in the elderly. Mechanisms of Ageing and Development 127:552-559. DOI: 10.1016/j.mad.2006.01.013

Ridker PM, Danielson E, Fonseca FAH, Genest J, Gotto AM, Kastelein JJP, Koenig W, Libby P, Lorenzatti AJ, MacFadyen JG, Nordestgaard BG, Shepherd J, Willerson JT, Glynn RJ, for the JUPITER Study Group. 2008. Rosuvastatin to prevent vascular events in men and women with 
570 elevated C-reactive protein. The New England Journal of Medicine 359:2195-2207. DOI: 571 10.1056/NEJMoa0807646

572

573

Ridker PM, Danielson E, Fonseca FAH, Genest J, Jr AMG, Kastelein JJP, Koenig W, Libby P, Lorenzatti AJ, MacFadyen JG, Nordestgaard BG, Shepherd J, Willerson JT, Glynn RJ, on behalf of the JUPITER Trial Study Group. 2009. Reduction in C-reactive protein and LDL cholesterol and cardiovascular event rates after initiation of rosuvastatin: a prospective study of the JUPITER trial. Lancet 373:1175-1182. DOI: 10.1016/S0140-6736(09)60447-5

Ross R. 1999. Atherosclerosis-an inflammatory disease. The New England Journal of Medicine 340:115-126. DOI: 10.1056/NEJM199901143400207

Smirnova I, Poltorak A, Chan EK, McBride C, Beutler B. 2000. Phylogenetic variation and polymorphism at the toll-like receptor 4 locus TLR4. Genome Biology 1(1): research002research002.10. DOI: 10.1186/gb-2000-1-1-research002

Vainas T, Stassen FRM, Bruggeman CA, Welten RJTJ, van den Akker LHJM, Kitslaar PJEHM, Peña AS, Morré SA. 2006. Synergistic effect of Toll-like receptor 4 and CD14 polymorphisms on the total atherosclerosis burden in patients with peripheral arterial disease. Journal of Vascular Surgery 44:326-332. DOI: 10.1016/j.jvs.2006.04.035

Wells GA, Shea B, O'Connell D, Peterson J, Welch V, Losos M, Tugwell P. 2011. The Newcastle-Ottawa Scale (NOS) for assessing the quality of nonrandomised studies in metaanalyses. Ottawa Health Research Institute. Available at http://www.ohri.ca/programs/clinical_epidemiology/oxford.asp/ (accessed20 Oct. 2011).

Wennberg P, Wensley F, Di Angelantonio E, Johansson L, Boman K, Rumley A, Lowe G, Hallmans G, Danesh J, Jansson JH. 2012. Haemostatic and inflammatory markers are independently associated with myocardial infarction in men and women. Thrombosis Research 129: 68-73. DOI: 10.1016/j.thromres.2011.05.015

Yang IA, Holloway JW, Ye S. 2003. TLR4 Asp299Gly polymorphism is not associated with coronary artery stenosis. Atherosclerosis 170:187-190. DOI: 10.1016/S0021-9150(03)00286-7

Yin YW, Sun QQ, Hua AM, Liu HL, Wang Q, Zhang BB. 2014. Toll-like receptor 4 gene Asp299Gly polymorphism in myocardial infarction: A meta-analysis of 15,148 subjects. Human Immunology 75:163-169. DOI: 10.1016/j.humimm.2013.11.005

Yuan M, Xia J, Ma L, Xiao B, Yang QD. 2010. Lack of the Toll-Like Receptor 4 Gene Polymorphisms Asp299Gly and Thr399Ile in a Chinese Population. International Journal of Neuroscience 120:415-420. DOI: 10.3109/00207451003778736 
611

612 Zee RYL, Hegener HH, Gould J, Ridker PM. 2005.Toll-like receptor 4 Asp299Gly gene 613 polymorphism and risk of atherothrombosis. Stroke 36:154-157. DOI: 614 10.1161/01.STR.0000149948.31879.f0

615

616 Zhang K, Zhang LS, Zhou B, Wang YY, Song YP, Rao L, Zhang L. 2012. Lack of association 617 between TLR4 Asp299Gly polymorphism and atherosclerosis: evidence from meta-analysis. 618 Thrombosis Research 130:203-208. DOI: 10.1016/j.thromres.2012.07.008 
631

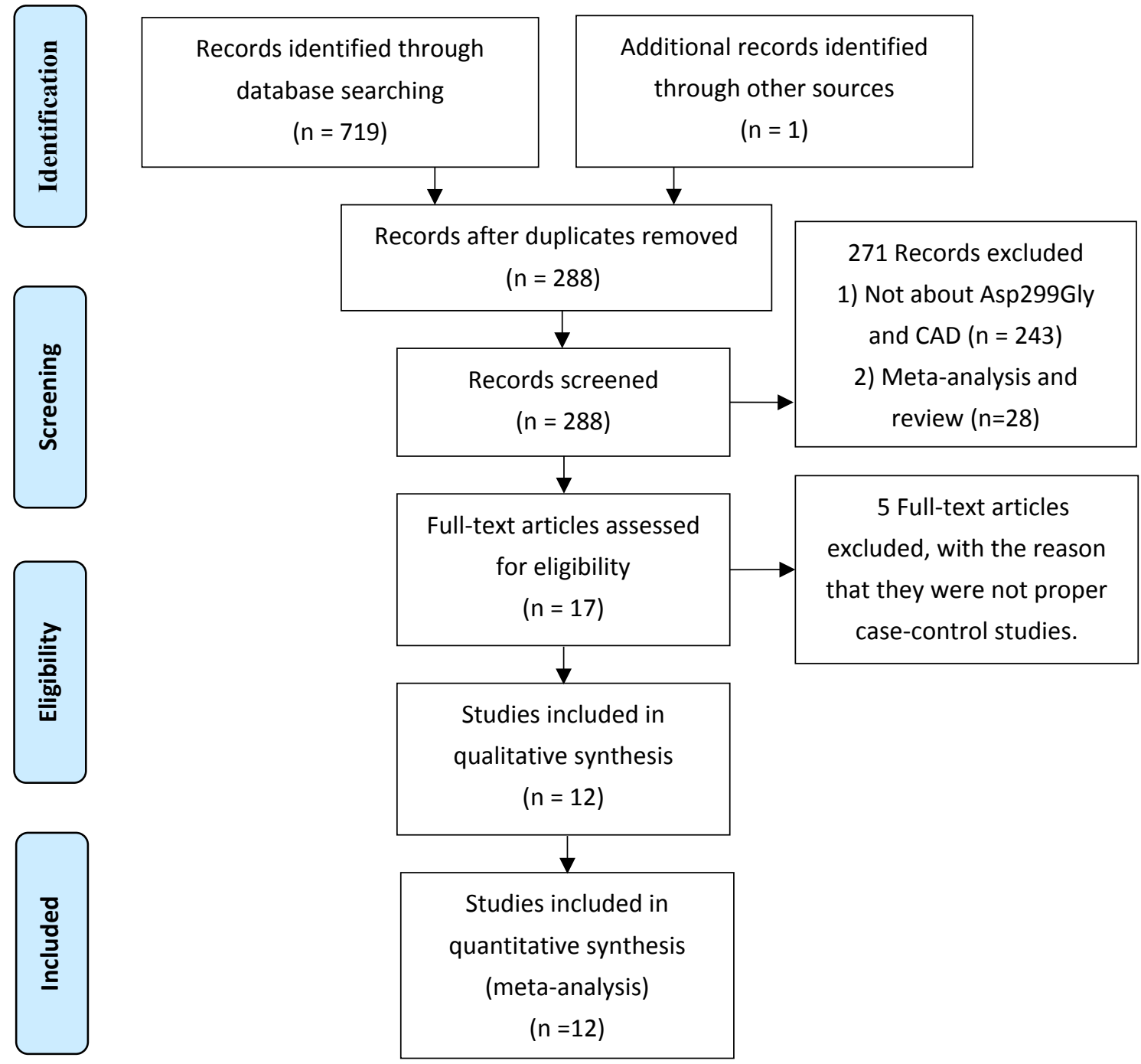

632

633

634 Figure 1: Flow diagram of the study selection process.

635 
A

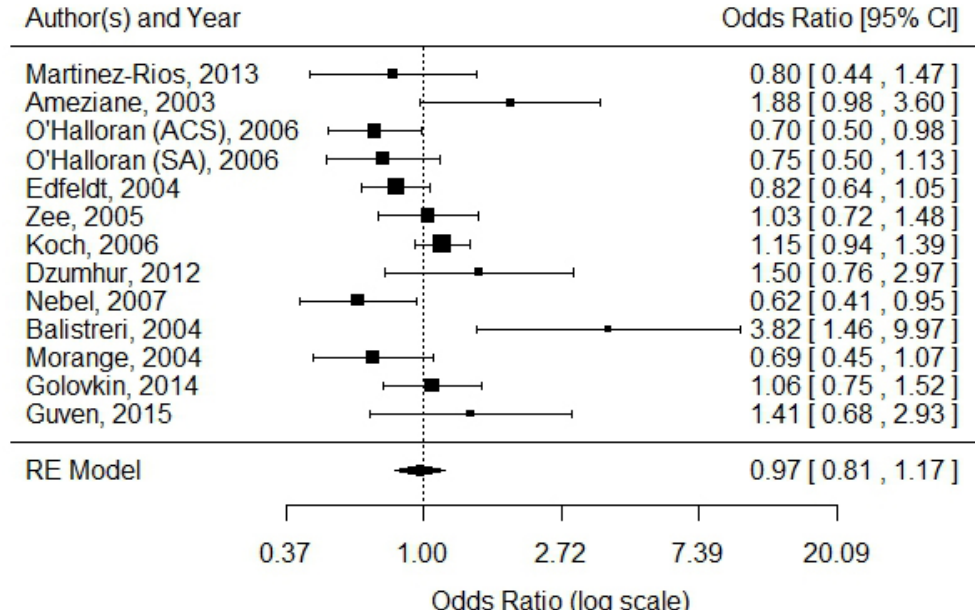

C

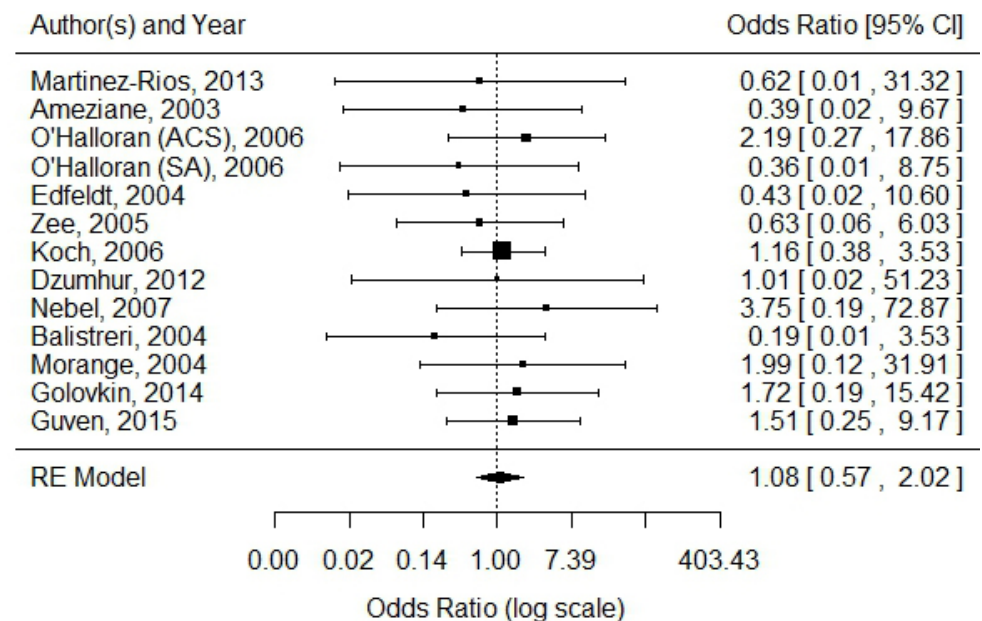

B

Author(s) and

\begin{tabular}{|c|c|c|c|c|}
\hline & & & & \\
\hline inez-Rios, 2013 & 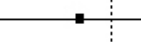 & & & $0.80[0.43,1.48]$ \\
\hline $\begin{array}{l}\text { Amezlane, } 2003 \\
\text { O'Halloran (ACS), } 2006\end{array}$ & $\longmapsto$ & & & $\begin{array}{l}1.87[0.96,3.66] \\
0.70[0.49,0.99]\end{array}$ \\
\hline O'Halloran (SA), 2006 & $=$ & & & $0.71[0.46,1.09]$ \\
\hline Edfeldt, 2004 & 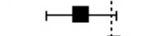 & & & $0.80[0.62,1.04]$ \\
\hline Zee, 2005 & & & & $1.02[0.70,1.49]$ \\
\hline $\begin{array}{l}\text { Koch, } 2006 \\
\text { Dzumhur, } 2012\end{array}$ & 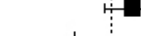 & & & $1.17[0.95,1.43]$ \\
\hline $\begin{array}{l}\text { Dzumhur, } 2012 \\
\text { Nebel, } 2007\end{array}$ & & & & $\begin{array}{l}1.56[0.76,3.17] \\
0.63[0.40,0.97]\end{array}$ \\
\hline Balistreri, 2004 & & & & $3.48[1.30,9.35]$ \\
\hline Morange, 2004 & & & & $0.68[0.43,1.08]$ \\
\hline Golovkin, 2014 & $=$ & & & $1.09[0.75,1.59]$ \\
\hline Guven, 2015 & & & & $1.67[0.73,3.81]$ \\
\hline RE Model & & & & $0.97[0.80,1.18]$ \\
\hline Г & T & $\top$ & $T$ & ᄀ \\
\hline 0.37 & 1.00 & 2.72 & 7.39 & 20.09 \\
\hline
\end{tabular}

D

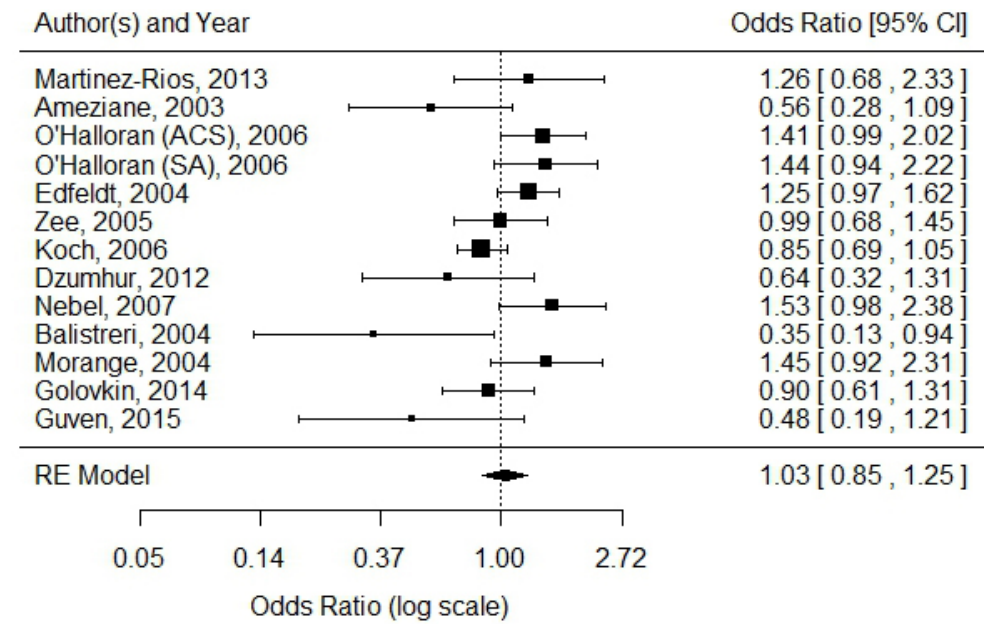

640 Figure 2: Forest plots of the association between TLR4 gene Asp299Gly polymorphism and CAD in different genetic models. A 641 (allelic model: G allele vs. A allele); B (dominant model: AA vs. GG+AG); C (recessive model: GG vs. AG + AA); D (superdominant model: $\mathrm{AG}$ vs. $\mathrm{AA}+\mathrm{GG})$. 
A

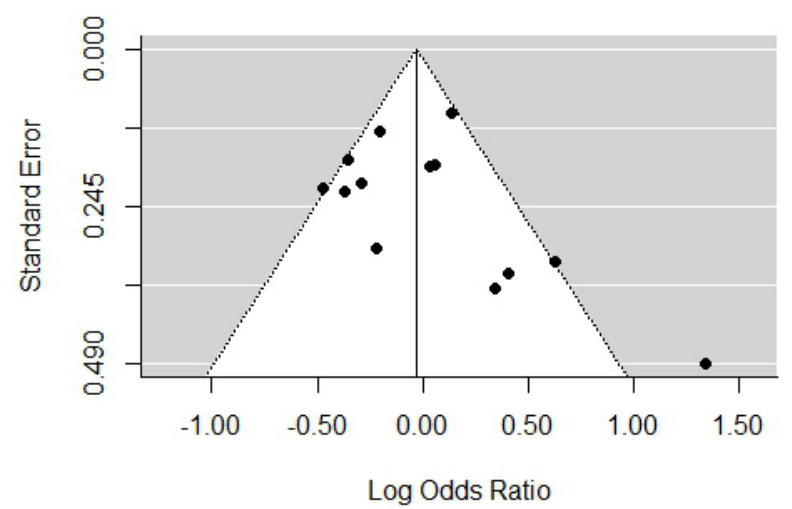

C

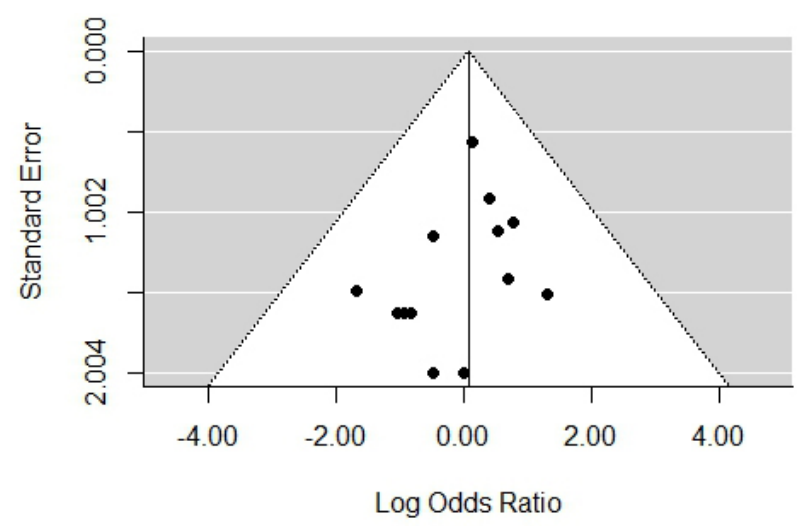

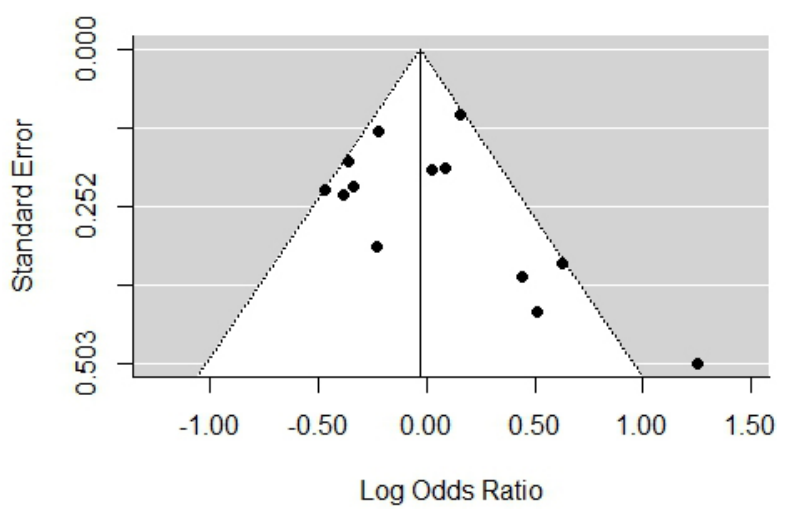

D

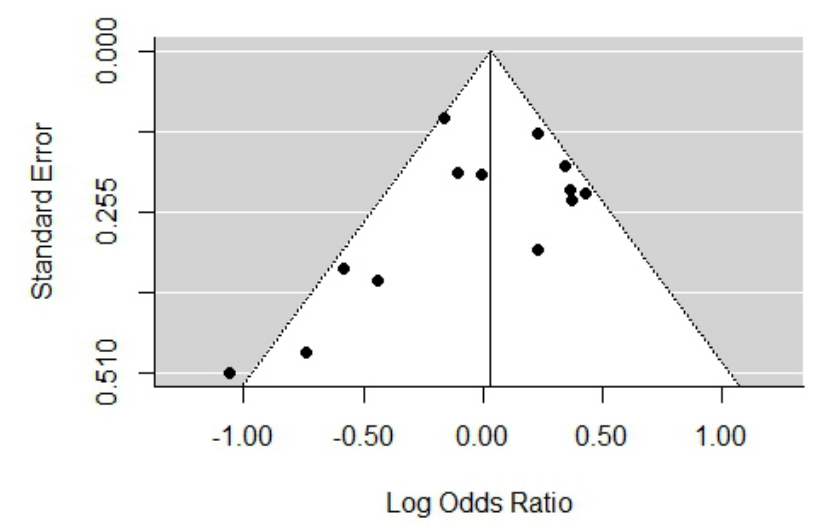

646 Figure 3: Funnel plots of the association between TLR4 gene Asp299Gly polymorphism and CAD in different genetic models. A 647 (allelic model: G allele vs. A allele); B (dominant model: AA vs. GG+AG); C (recessive model: GG vs. AG + AA); D (super648 dominant model: $\mathrm{AG}$ vs. $\mathrm{AA}+\mathrm{GG})$. 
A

Author(s) and Year

+ Edfeldt, 2004

+ Balistreri, 2004

+ Morange, 2004

+ Zee, 2005

+ O'Halloran (ACS), 2006

+ O'Halloran (SA), 2006

+ Koch, 2006

+ Nebel, 2007

+ Dzumhur, 2012

+ Martinez-Rios, 2013

+ Golovkin, 2014

+ Guven, 2015
Ameziane, 2003

Odds Ratio [95\% Cl]

$1.88[0.98,3.60]$

$1.17[0.52,2.62]$

$1.65[0.68,4.00]$

$1.23[0.70,2.18]$

$1.13[0.76,1.70]$

$1.01[0.73,1.41]$

$0.96[0.72,1.26]$

$0.98[0.77,1.25]$

$0.93[0.74,1.18$

$0.96[0.77,1.20]$

$0.95[0.77,1.17]$

$0.95[0.79,1.16]$

$0.97[0.81,1.17]$

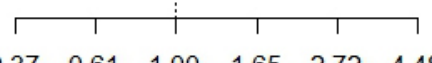

$\begin{array}{llllll}0.37 & 0.61 & 1.00 & 165 & 272 & 4.48\end{array}$

Odds Ratio (log scale)

C

\begin{tabular}{lll} 
Author(s) and Year & Odds Ratio [95\% Cl] \\
\hline Ameziane, 2003 & $0.39[0.02,9.67]$ \\
+ Edfeldt, 2004 & $0.41[0.04,3.96]$ \\
+ Balistreri, 2004 & $0.31[0.05,1.84]$ \\
+ Morange, 2004 & $0.53[0.12,2.40]$ \\
+ Zee, 2005 & $0.56[0.16,1.96]$ \\
+ O'Halloran (ACS), 2006 & $0.80[0.27,2.35]$ \\
+ O'Halloran (SA), 2006 & $0.74[0.27,2.05]$ \\
+ Koch, 2006 & \\
+ Nebel, 2007 & & $0.91[0.43,1.92]$ \\
+ Dzumhur, 2012 & & $0.99[0.48,2.05]$ \\
+ Martinez-Rios, 2013 & & $0.97[0.48,1.97]$ \\
+ Golovkin, 2014 & & $1.03[0.52,2.01]$ \\
+ Guven, 2015 &
\end{tabular}

$\begin{array}{lllll}0.00 & 0.02 & 0.14 & 1.00 & 7.39\end{array}$

Odds Ratio (log scale)
B

Author(s) and Year

Odds Ratio [95\% Cl]

Ameziane, 2003

+ Edfeldt, 2004

+ Balistreri, 2004

Morange, 2004

+ O'Halloran (ACS), 2006

+ O'Halloran (SA), 2006

+ Koch, 2006

+ Nebel, 2007

+ Dzumhur, 2012

+ Martinez-Rios, 2013

+ Golovkin, 2014

+ Guven, 2015

Odds Ratio (log scale)

\begin{tabular}{lll} 
Author(s) and Year & Odds Ratio [95\% Cl] \\
\hline Ameziane, 2003 & & $0.56[0.28,1.09]$ \\
+ Edfeldt, 2004 & & $0.89[0.40,1.96]$ \\
+ Balistreri, 2004 \\
+ Morange, 2004 \\
+ Zee, 2005 \\
+ O'Halloran (ACS), 2006 \\
+ O'Halloran (SA), 2006 \\
+ Koch, 2006 \\
+ Nebel, 2007 \\
+ Dzumhur, 2012 \\
+ Martinez-Rios, 2013
\end{tabular}

Figure 4: Cumulative meta-analysis of the association between TLR4 gene Asp299Gly polymorphism and CAD in different genetic models. A (allelic model: G allele vs. A allele); B (dominant model: AA vs. GG+AG); C (recessive model: GG vs. AG + AA); D (super-dominant model: AG vs. AA+GG). 
654

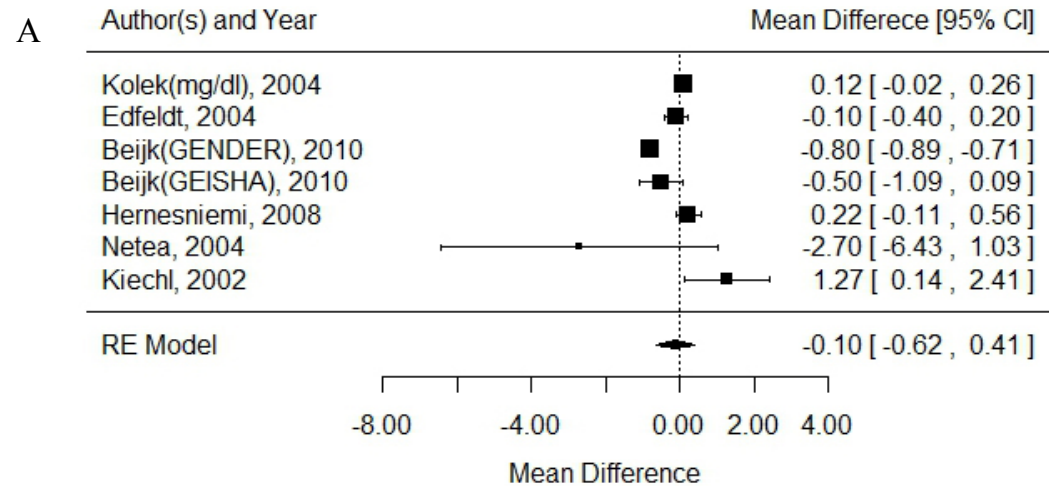

$\mathrm{B}$

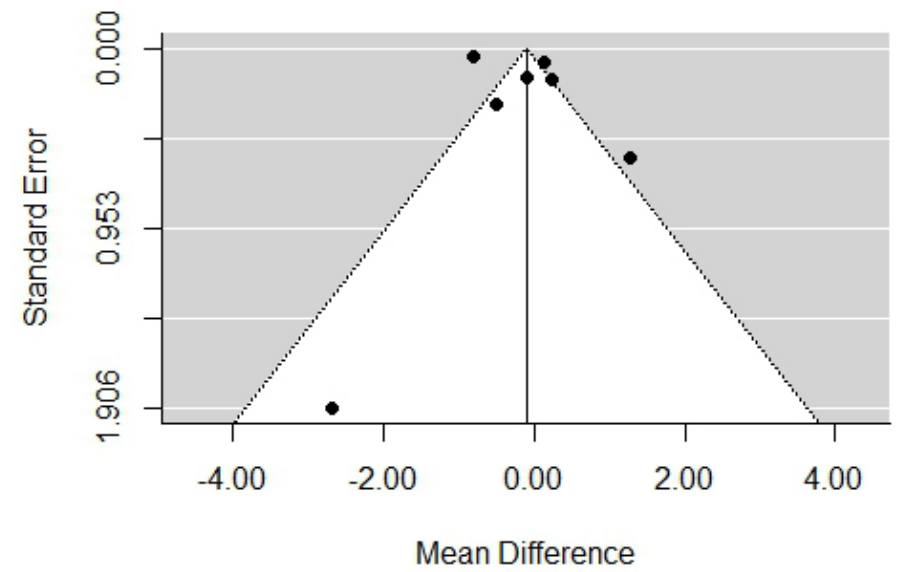

655

656 Figure 5: Forest and Funnel plots of the association between TLR4 gene Asp299Gly

657 polymorphism and CRP level. A (Forest plot); B (Funnel plot). 
659 Table 1: Characteristics of studies about the association between Asp299Gly and CAD.

660

\begin{tabular}{|c|c|c|c|c|c|c|c|c|c|c|c|c|c|c|c|}
\hline \multirow[b]{2}{*}{ Study } & \multirow[b]{2}{*}{ Year } & \multirow[b]{2}{*}{ Ethnicity } & \multirow[b]{2}{*}{ Region } & \multirow{2}{*}{$\begin{array}{c}\text { Disease } \\
\text { Category }\end{array}$} & \multirow{2}{*}{$\begin{array}{c}\text { Sample } \\
\text { Size(ca/co) }\end{array}$} & \multirow{2}{*}{$\begin{array}{c}\text { Sex } \\
\text { Ratio(m/f) }\end{array}$} & \multicolumn{4}{|c|}{ Cases } & \multicolumn{4}{|c|}{ Controls } & \multirow[b]{2}{*}{ HWE } \\
\hline & & & & & & & $\mathbf{A A}$ & $\mathbf{A G}$ & GG & $\begin{array}{c}\text { Sex } \\
\text { Ratio(m/f) }\end{array}$ & $\mathbf{A A}$ & $\mathbf{A G}$ & GG & $\begin{array}{c}\text { Sex } \\
\text { Ratio(m/f) }\end{array}$ & \\
\hline Martinez-Rios & 2013 & Mexican & Mexico & ACS & $457 / 283$ & $570 / 170$ & 425 & 32 & 0 & $368 / 89$ & 267 & 16 & 0 & $202 / 81$ & $\mathrm{Y}$ \\
\hline Ameziane & 2003 & Caucasian & France & ACS & $183 / 216$ & $353 / 46$ & 169 & 14 & 0 & $160 / 23$ & 187 & 28 & 1 & $193 / 23$ & $\mathrm{Y}$ \\
\hline O'Halloran & 2006 & Caucasian & Ireland & $\begin{array}{l}\text { ACS } \\
\text { SA }\end{array}$ & $1598 / 386$ & $1457 / 527$ & $\begin{array}{c}1048 \\
307\end{array}$ & $\begin{array}{c}182 \\
54\end{array}$ & $\begin{array}{l}7 \\
0\end{array}$ & $1232 / 366$ & 343 & 42 & 1 & $225 / 161$ & $\mathrm{Y}$ \\
\hline Edfeldt & 2004 & Caucasian & Sweden & MI & $1164 / 1508$ & $1838 / 834$ & 1038 & 126 & 0 & $821 / 343$ & 1374 & 133 & 1 & $1017 / 491$ & $\mathrm{Y}$ \\
\hline Zee & 2005 & Caucasian & US & MI & $370 / 695$ & $1065 / 0$ & 323 & 46 & 1 & $370 / 0$ & 605 & 87 & 3 & $695 / 0$ & $\mathrm{Y}$ \\
\hline Koch & 2006 & Caucasian & Germany & MI & $3657 / 1211$ & $3385 / 1483$ & 3283 & 360 & 14 & $2772 / 885$ & 1069 & 138 & 4 & $613 / 598$ & Y \\
\hline Dzumhur & 2012 & Caucasian & Croatia & MI & $119 / 120$ & $171 / 68$ & 104 & 15 & 0 & $81 / 38$ & 98 & 22 & 0 & $90 / 30$ & Y \\
\hline Nebel & 2007 & Caucasian & Germany & MI & $606 / 323$ & $929 / 0$ & 521 & 82 & 3 & $606 / 0$ & 293 & 30 & 0 & $323 / 0$ & $\mathrm{Y}$ \\
\hline Balistreri & 2004 & Caucasian & Italy & MI & $105 / 182$ & $287 / 0$ & 100 & 5 & 0 & $105 / 0$ & 155 & 23 & 4 & $182 / 0$ & $\mathrm{Y}$ \\
\hline Morange & 2004 & Caucasian & France & CAD & $247 / 490$ & $737 / 0$ & 211 & 35 & 1 & $247 / 0$ & 439 & 50 & 1 & $490 / 0$ & $\mathrm{Y}$ \\
\hline Golovkin & 2014 & Caucasian & Russia & CAD & $702 / 300$ & $797 / 205$ & 599 & 98 & 4 & $558 / 144$ & 253 & 46 & 1 & $239 / 61$ & $\mathrm{Y}$ \\
\hline Guven & 2015 & Turks & Turkey & CAD & $150 / 150$ & $149 / 151$ & 140 & 7 & 3 & $76 / 74$ & 134 & 14 & 2 & $73 / 77$ & $\mathrm{Y}$ \\
\hline
\end{tabular}

ACS, acute coronary syndrome; MI, myocardial infarction; CAD, coronary artery disease; HWE, Hardy - Weinberg equilibrium; Y, yes; N, no; Sample Size(ca/co), Sample Size(cases/controls); Sex Ratio(m/f): Sex Ratio(male/female). 
662

663 Table 2: Characteristics of studies about the association between Asp299Gly and CRP level. 664

\begin{tabular}{ccccccccc}
\hline \multirow{2}{*}{ Study } & \multicolumn{3}{c}{ AA(mg/l) } & & \multicolumn{3}{c}{ GG/GA(mg/l) } \\
\cline { 2 - 4 } \cline { 7 - 8 } & Mean & SD & $\mathbf{N}$ & & Mean & SD & N \\
\hline Kolek, 2004 (mg/dl) & 1.23 & 0.913 & 1725 & & 1.11 & 0.873 & 169 \\
Edfeldt, 2004 & 1.5 & 1.67 & 1791 & & 1.6 & 2 & 186 \\
Beijk, 2010 (GENDER) & 5.8 & 0.34 & 2344 & & 6.6 & 0.81 & 338 \\
Beijk, 2010 (GEISHA) & 5 & 0.5 & 202 & & 5.5 & 1.4 & 22 \\
Hernesniemi,2008 & 1.92 & 4 & 1812 & & 1.6952 & 2.7685 & 389 \\
Netea,2004 & 3.8 & 5.6 & 261 & & 6.5 & 10.6 & 32 \\
Kiechl,2002 & 3.72 & 7.8 & 755 & & 2.4455 & 3.7465 & 55 \\
\hline
\end{tabular}

665

666 


\section{Figure 1 (on next page)}

Figure 1: Flow diagram of the study selection process. 


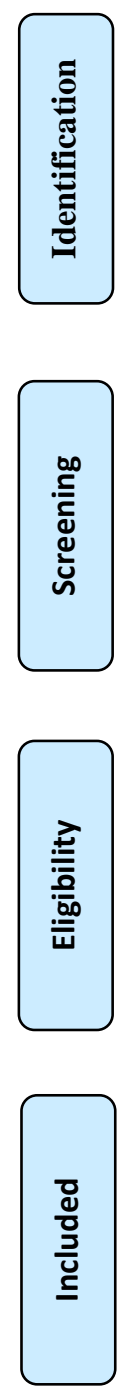

database searching

$$
(n=719)
$$

through other sources

$$
(n=1)
$$

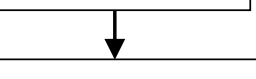

Records after duplicates removed

$$
\text { ( } n=288)
$$

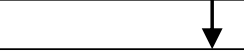

Records screened

$$
(n=288)
$$

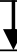

Full-text articles assessed

for eligibility

$$
(n=17)
$$

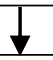

Studies included in

qualitative synthesis

$$
(n=12)
$$

5 Full-text articles

excluded, with the reason that they were not proper case-control studies. 
Figure 2 (on next page)

Figure 2: Forest plots of the association between TLR4 gene Asp299Gly polymorphism and CAD in different genetic models.

A (allelic model: $G$ allele vs. A allele); B (dominant model: AA vs. GG+AG); C (recessive model: $G G$ vs. $A G+A A$ ); $D$ (super-dominant model: $A G$ vs. $A A+G G$ ). 
A Author(s) and Year

PeerJ

Odds Ratio $[95 \% \mathrm{Cl}]$

Martinez-Rios, 2013

Ameziane, 2003

O'Halloran (ACS), 2006

O'Halloran (SA), 2006

Edfeldt, 2004

Zee, 2005

Koch, 2006

Dzumhur, 2012

Nebel, 2007

Balistreri, 2004

Morange, 2004

Golovkin, 2014

Guven, 2015

RE Model

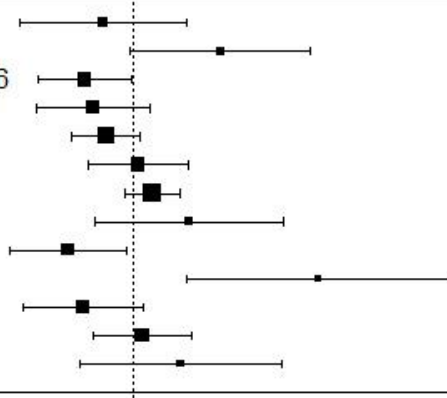

$0.80[0.44,1.47]$

$1.88[0.98,3.60]$

$0.70[0.50,0.98$

$0.75[0.50,1.13]$

$0.82[0.64,1.05]$

$1.03[0.72,1.48$

$1.15[0.94,1.39]$

$1.50[0.76,2.97$

$0.62[0.41,0.95$

$3.82[1.46,9.97$

$0.69[0.45,1.07]$

$1.06[0.75,1.52]$

$1.41[0.68,2.93]$

$0.97[0.81,1.17]$

0.37

1.00

2.72

7.39

20.09

Odds Ratio (log scale)

C Author(s) and Year

Odds Ratio [95\% Cl]

Martinez-Rios, 2013

Ameziane, 2003

O'Halloran (ACS), 2006

O'Halloran (SA), 2006

Edfeldt, 2004

Zee, 2005

Koch, 2006

Dzumhur, 2012

Nebel, 2007

Balistreri, 2004

Morange, 2004

Golovkin, 2014

Guven, 2015

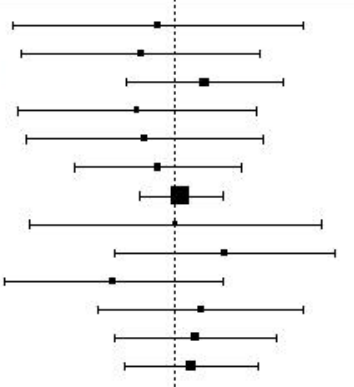

$0.62[0.01,31.32]$

$0.39[0.02,9.67$

$2.19[0.27,17.86$

$0.36[0.01,8.75$

$0.43[0.02,10.60$

$0.63[0.06,6.03$

$1.16[0.38,3.53]$

$1.01[0.02,51.23]$

$3.75[0.19,72.87$

$0.19[0.01,3.53$

$1.99[0.12,31.91$

$1.72[0.19,15.42$

$1.51[0.25,9.17]$

RE Model

$1.08[0.57,2.02]$
B Aatnofs)iandoear reviewed

Martinez-Rios, 2013

Ameziane, 2003

O'Halloran (ACS), 2006

O'Halloran (SA), 2006

Edfeldt, 2004

Zee, 2005

Koch, 2006

Dzumhur, 2012

Nebel, 2007

Balistreri, 2004

Morange, 2004

Golovkin, 2014

Guven, 2015

RE Model

D Author(s) and Year

Martinez-Rios, 2013

Ameziane, 2003

O'Halloran (ACS), 2006

O'Halloran (SA), 2006

Edfeldt, 2004

Zee, 2005

Koch, 2006

Dzumhur, 2012

Nebel, 2007

Balistreri, 2004

Morange, 2004

Golovkin, 2014

Guven, 2015

RE Model

403.43

$\begin{array}{lllll}0.00 & 0.02 & 0.14 & 1.00 & 7.39\end{array}$

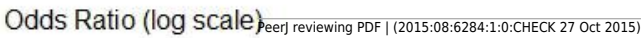

0.05

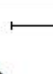
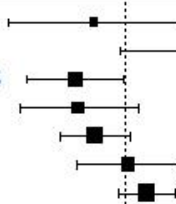

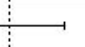

$+$
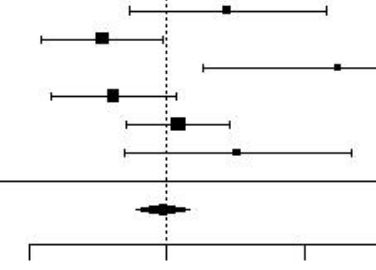

0.37

1.00

2.72

Odds Ratio (log scale)

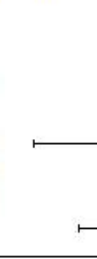

Odds Ratio [95\% Cl]

$0.80[0.43,1.48]$

$1.87[0.96,3.66]$

$0.70[0.49,0.99]$

$0.71[0.46,1.09$

$0.80[0.62,1.04]$

$1.02[0.70,1.49]$

$1.17[0.95,1.43$

$1.56[0.76,3.17]$

$0.63[0.40,0.97]$

$3.48[1.30,9.35]$

$0.68[0.43,1.08$

$1.09[0.75,1.59$

$1.67[0.73,3.81]$

$0.97[0.80,1.18]$

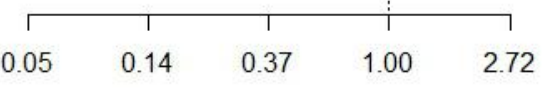

Odds Ratio (log scale)

Odds Ratio [95\% Cl]

$1.26[0.68,2.33]$

$0.56[0.28,1.09$

$1.41[0.99,2.02]$

$1.44[0.94,2.22]$

$1.25[0.97,1.62]$

$0.99[0.68,1.45]$

$0.85[0.69,1.05]$

$0.64[0.32,1.31]$

$1.53[0.98,2.38$

$0.35[0.13,0.94]$

$1.45[0.92,2.31]$

$0.90[0.61,1.31$

$0.48[0.19,1.21]$

\section{e)}

e)




\section{Figure 3 (on next page)}

Figure 3: Funnel plots of the association between TLR4 gene Asp299Gly polymorphism and CAD in different genetic models.

A (allelic model: G allele vs. A allele); B (dominant model: AA vs. GG+AG); C (recessive model: $G G$ vs. $A G+A A$ ); $D$ (super-dominant model: $A G$ vs. $A A+G G$ ). 
A

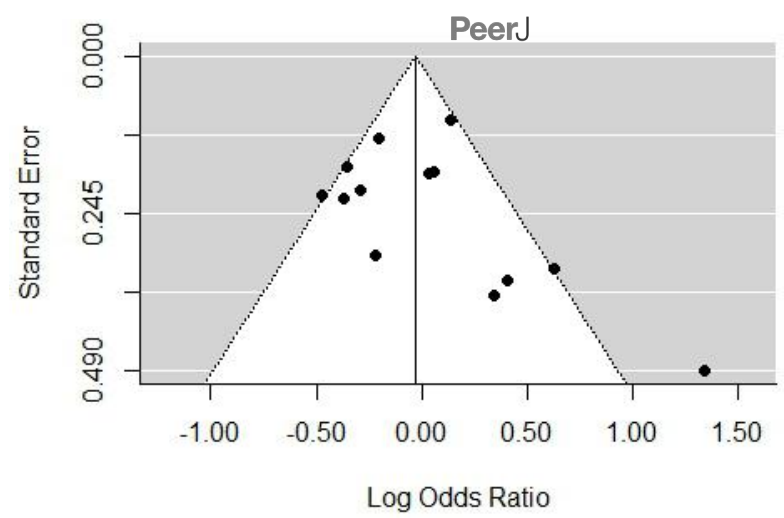

C

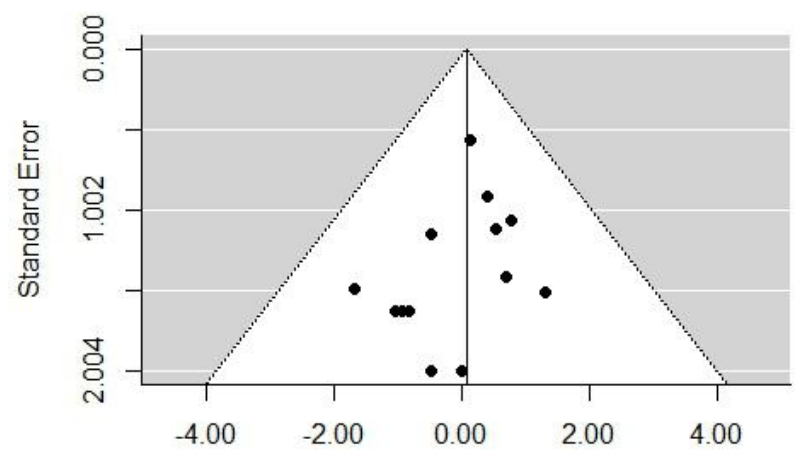

Log Odds Reertie ing PDF | (2015:08:6284:1:0:CHECK 27 oct 2015)
B Manus got to be reviewed

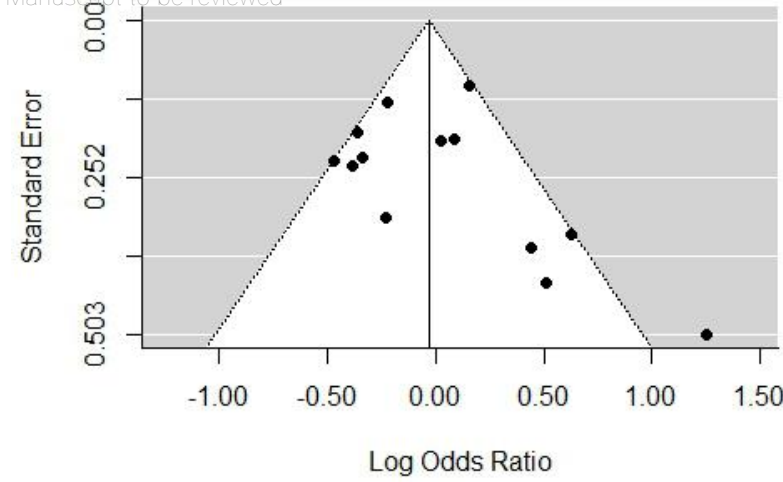

D

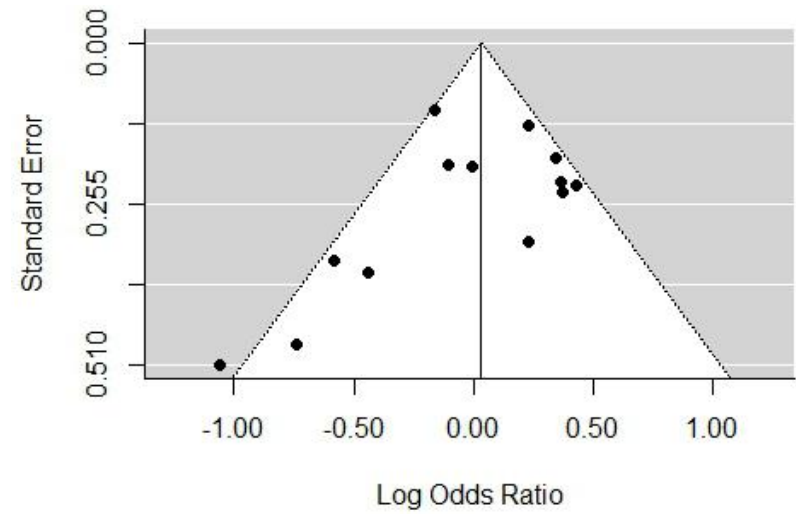




\section{Figure 4 (on next page)}

Figure 4: Cumulative meta-analysis of the association between TLR4 gene Asp299Gly polymorphism and CAD in different genetic models.

A (allelic model: G allele vs. A allele); B (dominant model: AA vs. GG+AG); C (recessive model: $G G$ vs. $A G+A A$ ); $D$ (super-dominant model: $A G$ vs. $A A+G G$ ). 
A Author(s) and Year

PeerJ

Odds Ratio $[95 \% \mathrm{Cl}]$

Ameziane, 2003

+ Edfeldt, 2004

+ Balistreri, 2004

+ Morange, 2004

+ Zee, 2005

+ O'Halloran (ACS), 2006

+ O'Halloran (SA), 2006

+ Koch, 2006

+ Nebel, 2007

+ Dzumhur, 2012

+ Martinez-Rios, 2013

+ Golovkin, 2014

+ Guven, 2015

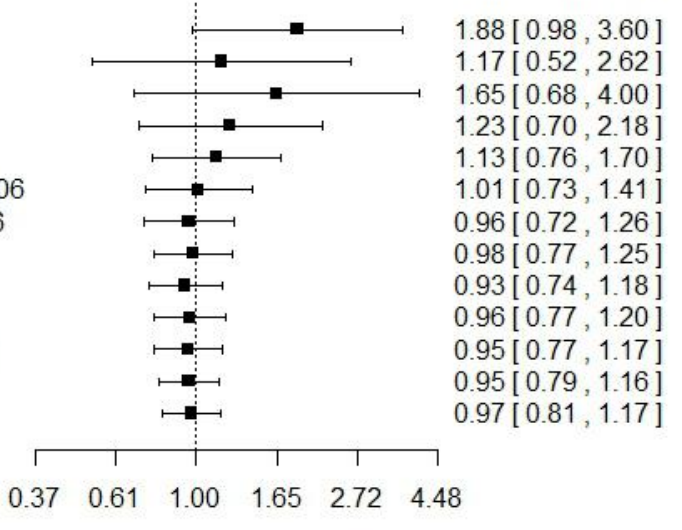

Odds Ratio (log scale)

C Author(s) and Year

Odds Ratio [95\% Cl]

Ameziane, 2003

+ Edfeldt, 2004

+ Balistreri, 2004

+ Morange, 2004

+ Zee, 2005

+ O'Halloran (ACS), 2006

+ O'Halloran (SA), 2006

+ Koch, 2006

+ Nebel, 2007

+ Dzumhur, 2012

+ Martinez-Rios, 2013

+ Golovkin, 2014

+ Guven, 2015

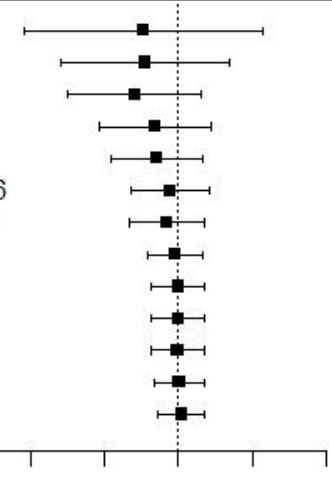

$\begin{array}{lllll}0.00 & 0.02 & 0.14 & 1.00 & 7.39\end{array}$

Odds Ratio (log scale) Peer) reviewing PDF | (2015:08:6284:1:0:CHECK 27 oct 2015

$1.03[0.52,2.01]$
B Aarthos(s) |andoYear reviewed

Odds Ratio $[95 \% \mathrm{Cl}]$

Ameziane, 2003

+ Edfeldt, 2004

+ Balistreri, 2004

+ Morange, 2004

+ Zee, 2005

+ O'Halloran (ACS), 2006

+ O'Halloran (SA), 2006

+ Koch, 2006

+ Nebel, 2007

+ Dzumhur, 2012

+ Martinez-Rios, 2013

+ Golovkin, 2014

+ Guven, 2015

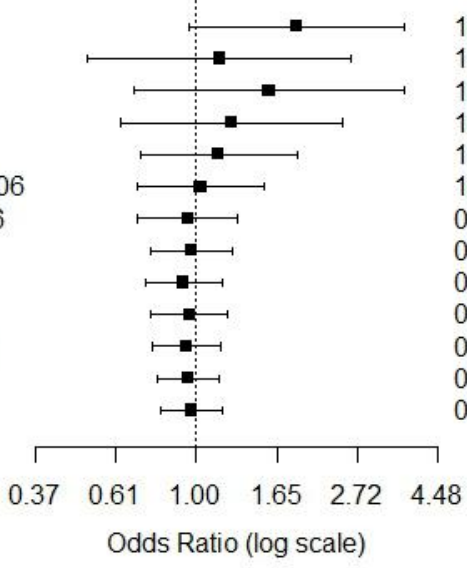

$1.87[0.96,3.66]$

$1.16[0.51,2.63]$

$1.57[0.68,3.64]$

$1.24[0.62,2.47]$

$1.15[0.70,1.87]$

$1.03[0.69,1.53]$

$0.95[0.69,1.29]$

$0.97[0.75,1.25]$

$0.92[0.73,1.17]$

$0.96[0.75,1.22]$

$0.94[0.76,1.16]$

$0.95[0.78,1.15]$

$0.97[0.80,1.18]$

Odds Ratio (log scale)

D Author(s) and Year

Odds Ratio $[95 \% \mathrm{Cl}]$

Ameziane, 2003

+ Edfeldt, 2004

+ Balistreri, 2004

+ Morange, 2004

+ Zee, 2005

+ O'Halloran (ACS), 2006

+ O'Halloran (SA), 2006

+ Koch, 2006

+ Nebel, 2007

+ Dzumhur, 2012

+ Martinez-Rios, 2013

+ Golovkin, 2014

$1.08[0.57,2.02]$

+ Guven, 2015

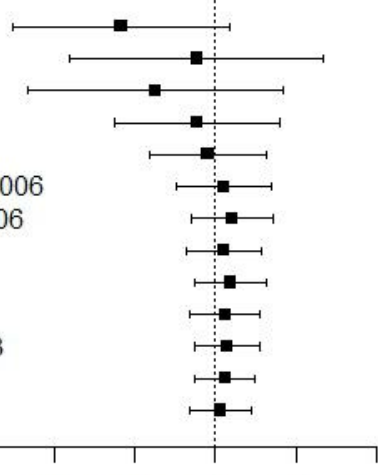

$0.56[0.28,1.09]$

$0.89[0.40,1.96]$

$0.69[0.31,1.52]$

$0.89[0.54,1.49]$

$0.95[0.66,1.37]$

$1.05[0.78,1.41]$

$1.11[0.86,1.44]$

$1.06[0.83,1.34]$

$1.10[0.88,1.37]$

$1.06[0.85,1.32]$

$1.08[0.88,1.32]$

$1.06[0.88,1.28]$

$1.03[0.85,1.25]$ 


\section{Figure $\mathbf{5}$ (on next page)}

Figure 5: Forest and Funnel plots of the association between TLR4 gene Asp299Gly polymorphism and CRP level.

A (Forest plot); B (Funnel plot). 
Kolek(mg/dl), 2004 Edfeldt, 2004 Beijk(GENDER), 2010 Beijk(GEISHA), 2010 Hernesniemi, 2008 Netea, 2004 Kiechl, 2002

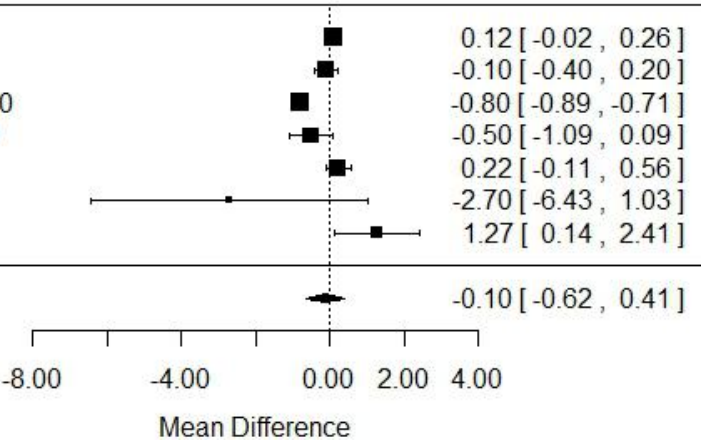

B

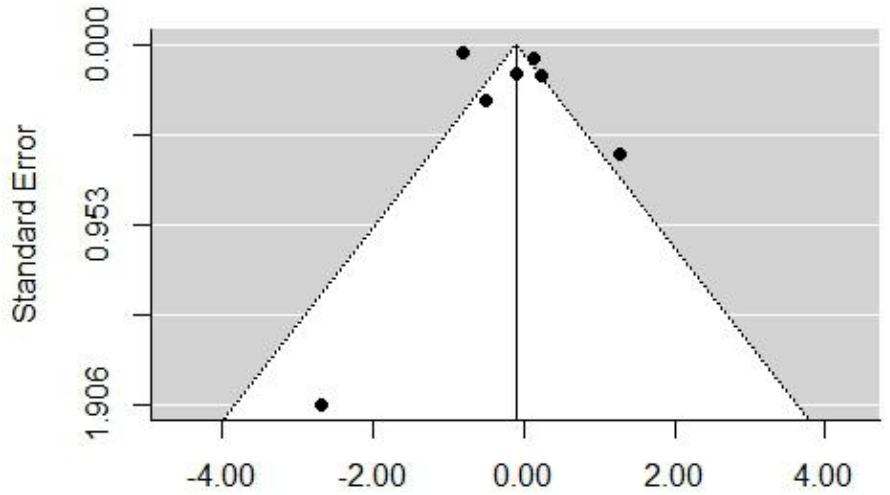




\section{Table $\mathbf{1}$ (on next page)}

Table 1: Characteristics of studies about the association between Asp299Gly and CAD. 


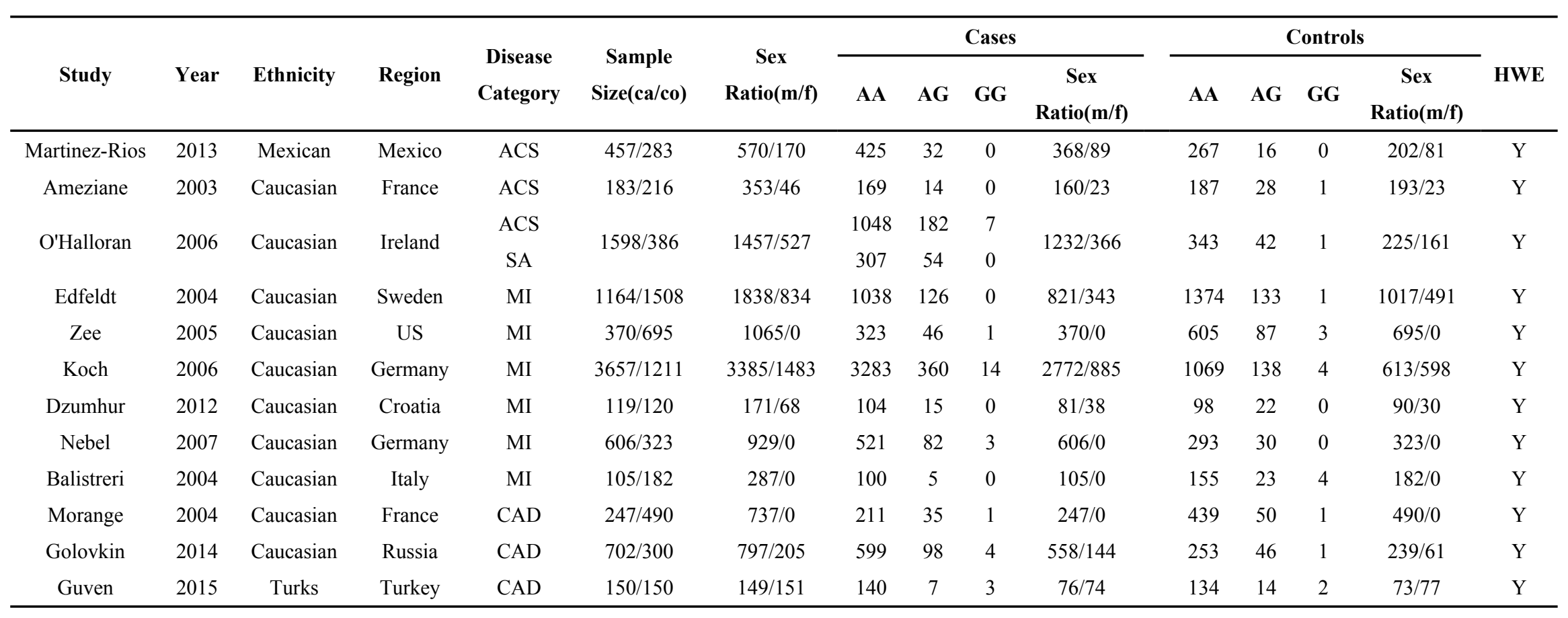

ACS, acute coronary syndrome; MI, myocardial infarction; CAD, coronary artery disease; HWE, Hardy - Weinberg equilibrium; Y, yes; N, no; Sample Size(ca/co), Sample Size(cases/controls); Sex Ratio(m/f): Sex Ratio(male/female). 


\section{Table 2 (on next page)}

Table 2: Characteristics of studies about the association between Asp299Gly and CRP level. 


\begin{tabular}{|c|c|c|c|c|c|c|}
\hline \multirow{2}{*}{ Study } & \multicolumn{3}{|c|}{$\mathbf{A A}(\mathrm{mg} / \mathrm{l})$} & \multicolumn{3}{|c|}{ GG/GA(mg/l) } \\
\hline & Mean & SD & $\mathbf{N}$ & Mean & SD & $\mathbf{N}$ \\
\hline Kolek, 2004 (mg/dl) & 1.23 & 0.913 & 1725 & 1.11 & 0.873 & 169 \\
\hline Edfeldt, 2004 & 1.5 & 1.67 & 1791 & 1.6 & 2 & 186 \\
\hline Beijk, 2010 (GENDER) & 5.8 & 0.34 & 2344 & 6.6 & 0.81 & 338 \\
\hline Beijk, 2010 (GEISHA) & 5 & 0.5 & 202 & 5.5 & 1.4 & 22 \\
\hline Hernesniemi,2008 & 1.92 & 4 & 1812 & 1.6952 & 2.7685 & 389 \\
\hline Netea,2004 & 3.8 & 5.6 & 261 & 6.5 & 10.6 & 32 \\
\hline Kiechl,2002 & 3.72 & 7.8 & 755 & 2.4455 & 3.7465 & 55 \\
\hline
\end{tabular}

2 